\title{
IN THE NAME OF SYARIAH? VIGILANTE VIOLENCE, TERRITORIALITY, AND MORAL AUTHORITY IN ACEH, INDONESIA
}

\section{David Kloos ${ }^{1}$}

In early 2011, local and national media reported on a violent incident in the village of Ajun Jeumpet, in the district of Aceh Besar, Aceh province. A group of (male) villagers had forced its way into a house to "arrest" the resident, a middle-aged man, as well as his visitor, an eighteen-year-old woman. The two were dragged out of the house and accused of khalwat (illicit proximity of an unmarried couple of opposing

David Kloos is a postdoctoral researcher at the Royal Netherlands Institute for Southeast Asian and Caribbean Studies (KITLV), in Leiden.

${ }^{1}$ The research conducted for this article was supported partly by the Faculty of Arts, VU University Amsterdam, and partly by the Islam Research Programme-Jakarta, funded by the Ministry of Foreign Affairs of the Netherlands. Final revisions were made at the International Institute of Asian Studies (IIAS) and Royal Netherlands Institute for Southeast Asian and Caribbean Studies (KITLV), Leiden. All of my interlocutors in Aceh are gratefully acknowledged. Muhajir Al-Fairusy kindly assisted me in arranging some of the interviews. I thank Kees van Dijk, Gerry van Klinken, two anonymous reviewers, and the editors of Indonesia for their helpful comments on earlier versions of this essay. Many thanks also to Moch Nur Ichwan and Reza Idria, the other researchers in the IRP Aceh cluster, as well as Michael Feener and Annemarie Samuels, my co-editors on a forthcoming volume on Islam and the state in Aceh, for many stimulating conversations. I am grateful, finally, to Marise van Amersfoort, Léon Buskens, and Nico Kaptein for supervising the IRP "team Indonesia" and for their personal support. The views presented in this paper represent those of the author and are in no way attributable to the IRP office or the ministry. 
sexes), a criminal offense under syariah legislation. ${ }^{2}$ According to local reporters, the man was an amateur photographer while the woman acted as his "model." Reports about what happened after the raid diverge. Some observers stated that the couple was handed over, immediately, to the Wilayatul Hisbah $(\mathrm{WH}$, the so-called "syariah police $^{\prime \prime}$ ). Other reports stated that they were taken to the local police station first. ${ }^{3}$ Either way, a few months after the arrest, the couple was brought before the syariah court (Mahkamah Syariah) in Jantho, the administrative center of Aceh Besar district. Both of them were found guilty and sentenced to the lash. The sanction-seven strokes for the man, four for the woman-was carried out on April 8, 2011. In the meantime, three men had been accused by the woman's parents of sexually harassing their daughter. The young woman had been stripped bare and grabbed indecently during the arrest. One man, a forty-five-year-old civil servant, was taken into custody and brought to trial. The others were not.

Alarmed by this apparent lack of interest in persecuting vigilantes, local human rights activists issued a statement. The provincial branch of KontraS, a renowned Indonesian human rights group, estimated that more than a hundred cases of street justice related to syariah had occurred in the preceding three years, including unlawful imprisonment, raids of public spaces, and beatings. KontraS coordinator Hendra Fadli urged the State Syariah Agency (Dinas Syariat Islam) to "educate people in the province to prevent them from taking justice into their own hands in the name of Islam. ${ }^{4}$ Evi Narti Zain, executive director of the human rights coalition HAM Aceh (Hak Asasi Manusia Aceh), added that "conducting street justice and vigilante crackdowns on people's homes simply because of alleged violations of Shariah law constitutes a violation of human rights." ${ }^{5}$

Vigilante violence, or "street justice," is one of the most contentious aspects of the current implementation of syariah in Aceh. According to human rights advocates, the Islamic penal code (which was introduced in the early 2000s) has encouraged local communities to police public morality in their own villages and neighborhoods, spy on their neighbors' activities, and carry out violent punishment of alleged violators of syariah-based norms. Disciplinary measures include heavy-handed arrests, beatings, forced marriages, sexual harassment, and the practice of publicly cleansing accused wrongdoers with sewage water. ${ }^{6}$ Reports such as these have stated that local

\footnotetext{
${ }^{2}$ The spelling system employed in this article for Indonesian terms of Arabic origin is that conventionally used in Indonesia. I have not included diacritics, except when directly quoting published materials using other systems. Thus, the term "shari ' $a$ " (literally "way" or "path," commonly translated as "Islamic law") has been transliterated here as "syariah." It should be noted, however, that in Aceh, various transliterations are in use, including "syariah" and "syariat (Islam)."

3 "Pasangan selingkuh dicambuk 9 kali," Serambi Indonesia, A pril 9, 2011; "Fotografer 'Bugil' Dihukum Cambuk," A pril 9, 2011, http:/ / www.jpnn.com/ read/2011/04/09/89117/Fotografer-\%27Bugil\%27-

Dihukum-Cambuk-, accessed July 29, 2014; "Indonesian Couples Caned over Extramarital Affairs," April 9, 2011, http:/ / www.thejakartaglobe.com/archive/indonesian-couples-caned-over-extramarital-affairs/, accessed July 29, 2014; and "Pelaku mesum pingsan setelah dihukum cambuk," http://www. mediaindonesia.com/ read/2011/04/04/216484/ 126/101/Pelaku-Mesum-Pingsan-setelah-DihukumCambuk, accessed November 13, 2012.

4 "Activists Denounce Shariah Vigilante Justice in Aceh," April 13, 2011, www.thejakartaglobe.com, accessed December 12, 2012.

${ }^{5}$ Ibid.

${ }^{6}$ For example, a report by the International Crisis Group stated that the "existence" of the Wilayatul Hisbah alone "encourages citizens to report their friends and neighbors for suspected breaches of moral
} 
authorities, including the police, district and provincial administrators, and magistrates, do little to curb these human rights abuses and in some cases even openly approve of them. These conclusions contrast sharply with the opinions voiced by prominent officials involved in the process of syariah implementation, who typically state that Islamic law should be regarded as a form of protection against, rather than encouragement of, vigilante violence. ${ }^{7}$

Although I share many of these concerns, I am critical of viewing vigilante violence and morality policing exclusively, or even primarily, within the framework of Islamic law. I recognize three problems. Firstly, the exclusivist framework of state syariah offers few possibilities for understanding why people in Aceh think that violence is justified in some situations and not in others, even if the alleged offence appears to be the same. Secondly, a tight focus on state syariah offers little room for the analysis of different kinds of violence and its interpretation by people in Aceh. Thirdly, and most importantly, a dominant focus on the legal particularities of syariah hides from view the ways in which local conflicts about public morality issues are connected to broader contestations about moral authority and public space in the Acehnese post-conflict, post-tsunami context.

This essay discusses the occurrence of vigilante violence in Aceh and its relation to the project of state syariah. I will argue that the important underlying dynamic is not the implementation of Islamic law as such, but a much deeper, more complex and versatile conflict about social control and moral authority in present-day Aceh. This contestation is informed both by the discursive genealogies of particular normative traditions (which include, but are not limited to, the various interpretations of Islamic law), and by the lived realities of the post-conflict, post-disaster context. As I will try to show, syariah serves as a powerful label for explaining and justifying action. At the same time, an exclusive focus on state syariah conceals the process by which the state has interacted with local actors to formulate, enforce, and contest "local" norms. Locality, I argue, is both a crucial and a neglected lens for analyzing the present struggle for authority in Aceh and for understanding the social, cultural, and political patterns that make possible, or prevent, the use of violence by non-state actors. Central, in this respect, is the extent to which village-level authorities are able to reconcile, on the one hand, their role as agents of the state, and, on the other hand, their role in protecting the moral spaces connected to the idea-and centrality in Acehnese social and cultural life-of "village community" (A: gampong).

The following sections deal with broad social and political changes as well as specific cases of morality policing. The essay builds on a diverse set of data, including literature, media reports, formal interviews, and everyday fieldwork observations, collected during multiple visits to Aceh in the period 2008-12. I begin with some conceptual and comparative reflections on vigilantism in Indonesia, then proceed with an outline of historical and socio-political developments in Aceh. The core of the article

behavior." International Crisis Group, "Islamic Law and Criminal Justice in Aceh," Asia Report No. 117, 2006. Human Rights Watch advanced a similar argument, stating that the law on khalwat "encourages private individuals to participate in the implementation of the law." Human Rights Watch, "Policing Morality: Abuses in the Application of Sharia in Aceh, Indonesia," December 2010.

${ }^{7}$ See, for example, R. Michael Feener, Shari'a and Social Engineering: The Implementation of Islamic Law in Contemporary Aceh (Oxford: Oxford University Press, 2013), p. 243. 
is formed by the third section, which discusses in detail a number of cases. In the final section before the conclusion, I elaborate on the specificities of these cases to investigate, at a more general level, the connections between vigilante violence and state practice. The conclusion revisits and draws some broader implications from my argument about the relationship between vigilantism, the social construction of locality, and the struggle for moral authority in contemporary Aceh.

\section{Vigilantism, the State, and the Problem of Locality}

The study of Aceh has tended to privilege the region's history of rebellion and the strong "piety" of its inhabitants. I have dealt with the problems of (ethnic) stereotypes and Acehnese exceptionalism elsewhere. ${ }^{8}$ As for my present concern with vigilante violence, two problems should be identified. Firstly, an emphasis on resistance against the state tends to close off, beforehand, the analysis of state practices developing on the ground and the role in this process of the Acehnese themselves. Secondly, a focus on regional particularities poses a risk that observers might ignore the fact that vigilante violence is, simultaneously, an international phenomenon and a national concern, tied to the social and political changes resulting from the collapse of the New Order regime in $1998 .{ }^{9}$ These problems may be avoided by shifting the level of analysis, simultaneously, upwards, taking into account global and national developments, and downwards, toward a grounded analysis of local tensions and contestations.

A key mediating force between these different levels is the state. In this article, the state is viewed simultaneously as an actor and as an arena of contestation. ${ }^{10}$ In order to answer the question why citizens, in particular historical and cultural contexts, decide to take the law into their own hands, it is insufficient to point at the "absence" of the state or its incapacity to provide for justice. Instead, we must be sensitive to the context of a fragmented state, consisting of a "patchwork of de facto jurisdictions, each with its own 'morality' and each policed by self-appointed vigilantes, as well as by the police and the army." ${ }^{11}$ In most cases, "non-state or self-policing has a very long historical trajectory to which the history of state policing, not just state failures, has contributed in large measure." ${ }^{12}$ In other words, both the role of the state and the "systemic"

\footnotetext{
${ }^{8}$ David Kloos, "A Crazy State: Violence, Psychiatry, and Colonialism in Aceh, ca. 1910-1942," Bijdragen tot de Taal-, Land-, en Volkenkunde 170,1 (2014); and "Images of Violence and Piety in Aceh," in Islam, Politics, and Change: The Indonesian Experience, 1998-2013, ed. Léon Buskens, Kees van Dijk and Nico Kaptein (Leiden: Leiden University Press, forthcoming).

${ }^{9}$ The wave of communal violence after 1998 must be understood, at least partly, in the context of the transition to democracy. In the words of Edward Aspinall: "The 'national model' by which minority groups had been incorporated into Indonesia's political system, and by which they attained access to material resources, was suddenly up for re-negotiation. The field of opportunity opened up by the regime's collapse encouraged some groups to push violently to change the terms of their incorporation to their advantage, resolve long-standing grievances, get better access to natural or state resources, and so on. Most did so by peaceful political mobilization; some did so violently." Edward Aspinall, "Ethnic and Religious Violence in Indonesia: A Review Essay," Australian Joumal of International Affairs 62,4 (2008): 560.

${ }^{10}$ See Joshua Barker and Gerry van Klinken, "Reflections on the State in Indonesia," in State of Authority: The State in Society in Indonesia, ed. Gerry van Klinken and Joshua Barker (Ithaca, NY: Cornell Southeast Asia Program Publications, 2009).

${ }^{11}$ Joshua Barker, "Vigilantes and the State," Social Analysis 50,1 (2006): 206.

${ }^{12}$ Atreyee Sen and David Pratten, "Global Vigilantes: Perspectives on Justice and Violence," in Global Vigilantes, ed. David Pratten and Atreyee Sen (London: Hurst \& Company, 2007), p. 6.
} 
aspects of violence (that is, the ways in which violence is "sedimented" in everyday life), is always rooted in complex historical processes. ${ }^{13}$

In colonial Indonesia, the state made extensive use of local strongmen to maintain its authority, a situation that finds an analogy in the late New Order, during which it became increasingly difficult to distinguish between the instruments of state repression and local criminals or thugs (preman) ${ }^{14}$ These blurred boundaries go some way in explaining why, after 1998, it became "common for citizens themselves to mete out punishments to those suspected as having committed a crime or an offense." ${ }^{15}$ "Mob justice," instead of a direct result of state weakness, must be viewed as an established repertoire of action extending well into the past. "What changed in 1998," writes Freek Colombijn, "was not so much the degree of dissatisfaction with the weak judicial apparatus, but the changed perception of the risk that participants in mob justice will be prosecuted by a weak judiciary." ${ }^{\prime 16}$

Similar arguments have been advanced with regard to religiously motivated violence. ${ }^{17}$ In Lombok, where religious minorities have been threatened by civilian "security groups" claiming to represent the island's Muslim majority, state officials "find it more difficult [compared to the New Order period] to demonize those who upset stability and order." ${ }^{18}$ Nicholas Herriman, in his work on the killing of alleged "sorcerers" in East Java in 1998-99, writes that this form of "community justice" existed before, but that it was held in check by the state. In 1998, "stronger doubts" emerged with regard to the willingness and capacity of the state to take action against such violence, "resulting in an almost universal sense of an opportunity [kesempatan] to kill the 'sorcerers' in one's village." ${ }^{19}$ While the killings in East Java were committed

${ }^{13}$ Patricia Spyer, "Some Notes on Disorder in the Indonesian Postcolony," in Law and Disorder in the Postcolony, ed. Jean Comaroff and John L. Comaroff (Chicago, IL: University of Chicago Press), p. 189.

${ }^{14}$ Joshua Barker, "State of Fear: Controlling the Criminal Contagion in Suharto's New Order," Indonesia 66 (October 1998): 7-42; Henk Schulte Nordholt, "A Genealogy of Violence," in Roots of Violence in Indonesia: Contemporary Violence in Historical Perspective, ed. Freek Colombijn and Jan Thomas Lindblad (Leiden: KITLV Press, 2002); and Loren Ryter, "Pemuda Pancasila: The Last Loyalist Free Men of Suharto's Order?," Indonesia 66 (October 1998): 45-73.

${ }^{15}$ Barker, "Vigilantes and the State," p. 203.

${ }^{16}$ Freek Colombijn, "Maling, Maling! The Lynching of Petty Criminals," in Roots of Violence in Indonesia, ed. Colombijn and Lindblad, p. 324.

${ }^{17}$ Violence against religious minorities, alleged "enemies of Islam," or social deviants more generally has become a common feature of post-New Order Indonesia. Christians, but also Muslim minorities (notably Shi'a communities and members of the minority Ahmadiyah sect), as well as individuals and local communities accused of engaging in "un-Islamic" behavior," have become the target of vigilantes. In 2012, the Jakarta-based SETARA Institute for Democracy and Peace counted 264 violations of freedom of religion, compared to 135 incidents in 2007. See "Report on Freedom of Religion and Belief in 2007," http:/ / www.setara-institute.org/en/ content/ report-freedom-religion-and-belief-2007, accessed April 8, 2014. For the position of the Ahmadiyah, see International Crisis Group, "Indonesia: Implications of the Ahmadiyah Decree," Asia Briefing No. 78 (2008). For a more general attempt to explain the "conservative turn" in Indonesian Islam, see Martin van Bruinessen, ed., Contemporary Developments in Indonesian Islam: Explaining the "Conservative Turn" (Singapore: Institute of Southeast Asian Studies, 2013).

${ }^{18}$ Kari Telle, "Vigilante Citizenship: Sovereign Practices and the Politics of Insult in Indonesia," Bijdragen tot de Taal-, Land-, en Volkenkunde 169-2/3 (2013): 207.

${ }^{19}$ Nicholas Herriman, "Sorcerer' Killings in Banyuwangi: A Re-examination of State Responsibility for Violence," Asian Studies Review 31,1 (March 2007): 70. Often, Herriman found, the people responsible for the killings were "family, neighbors, and friends" of the victims. He thus distinguished between the role of ordinary villagers and the views that have cited conspiracies (for example, by the army) or emphasized "state responsibility." James Siegel, in his investigation of the same phenomenon, argued that the killings 
out of a real sense of threat, the violence was also encouraged and legitimized by political and religious leaders, who actively produced, or reproduced, local myths, rumors, and fears. ${ }^{20}$ In Lombok, the opposite happened. Local gangs used rumors and (the threat of) violence to raise their agendas, forcing the state to come to action and "correct those who provoked their outrage in the first place." ${ }^{21}$

In both cases, an appeal to the need to uphold "order" and "justice" is central. It is rather conspicuous, then, that the literature about vigilante violence in Indonesia pays relatively little attention to the question of how non-state actors decide what is "just," and what social and political institutions they turn to at those times when they are uncertain about this. As John Comaroff and Jean Comaroff have emphasized, in postcolonial societies violence and the law are intimately related. ${ }^{22}$ But if the use of violence is part of a cultural "repertoire," then what else is there to be found in this repertoire that speaks to the threats and injustices that destabilize the social or moral "order"? In my view, conceptions of the law-and their relation to authority-cannot be understood properly without examining the ways in which these concepts connect to a sense of the "local." Here, I refer to "questions of location, timing, durability and modes of violence," ${ }^{23}$ but also to a less explored problem, namely, how the dialectic between violence and authority depends on the very perception of "locality" itself. Moral authority exists because people in a certain place-or moving between different places-vest their trust in, and prepare to submit to, particular leaders or institutions. At the same time, there is a natural tension between senses of the local and the normative claims that aim to transcend, break through, or abolish spatial boundaries. Thus, any analysis of morality policing requires careful conceptual reflection on the social construction, everyday experience, and salience of the local.

All forms of violence are, ultimately, localized. However, compared to outbreaks of large-scale political and communal violence, vigilantes seem to depend even more on a clear (or at least persuasive) definition of the local. Vigilantism (and related forms of "routine," "small-scale," and "social" violence) may be distinguished from other forms of communal violence on the basis that it is not commonly labeled, at least not directly, as "political." ${ }^{24}$ Connected to this is the fact that social violence takes place, typically, in villages (rather than, for example, cities and city centers, industrial complexes, or sites

must be attributed to a fundamental uncertainty (and resulting anxiety) about the question what, exactly, is meant by the term "witch" (tukang santet, or tukang sihir). The New Order played a central role in defining the qualities and attributes of the forces of "good" and of "evil." Once the regime collapsed, witch hunts provided communities with a "means for local control of general-or national-malevolence when state control failed." See James T. Siegel, Naming the Witch (Stanford, CA: Stanford University Press, 2005), p. 161.

${ }^{20}$ Nicholas Herriman, "The Great Rumor Mill: Gossip, Mass Media, and the Ninja Fear," The Journal of Asian Studies 69,3 (August 2010).

${ }^{21}$ Telle, "Vigilante Citizenship," p. 207.

${ }^{22}$ John L. Comaroff and Jean Comaroff, "Law and Disorder in the Postcolony: An Introduction," in Law and Disorder in the Postcolony, ed. Comaroff and Comaroff (Chicago, IL: The University of Chicago Press, 2006). As Barker states, paraphrasing Walter Benjamin, vigilante violence, especially when drawing on established (religious and other) moral frameworks, has "law-making" qualities. Barker, "Vigilantes and the State," p. 206.

${ }^{23}$ Aspinall, "Ethnic and Religious Violence in Indonesia," p. 559.

${ }^{24}$ For a recent and important collective attempt to elaborate, both analytically and methodologically, on this distinction, see Ashutosh Varshney, ed., Collective Violence in Indonesia (Boulder, CO: Lynne Rienner Publishers, 2010). 
vested with or symbolizing political power). ${ }^{25}$ While this may lead to new questions about the nature of political violence in Indonesia, it also means that explanations for vigilante violence must take into account the ways in which moral spaces are constructed and tied to ideas about the concept of the village, including its social as well as its spatial characteristics.

In order to address the problem of the spatial distribution of violence, moreover, it is necessary to ask how local factors relate to broad regional and national trends and concerns. Bridget Welsh, who combined quantitative data (based on newspaper reporting) and ethnographic case studies to study mob violence (keroyakan) in four different Indonesian provinces, places the emphasis on local leadership and the extent to which, in particular regions, mob violence is socialized or historically "imprinted." ${ }^{26}$ Mobbing, Welsh argues, occurs when local leaders either legitimize the violence, fail to take action against it, or act as mobilizing actors themselves. While I subscribe to Welsh's argument that local leadership is central, her approach allows little conceptual footing from which one might analyze the construction, negotiation, and limitation of leadership roles in particular settings (i.e., social and cultural), or the question of how these processes are shaped by concepts of space and territory. More useful, in this respect, is Joshua Barker's insightful study of security in urban Bandung, in which he distinguishes between practices of "surveillance" and practices of "territoriality," each pertaining to a very different concept of security. ${ }^{27}$ The actions of the police and other state institutions categorized as hansip (pertahanan sipil, "civil defense") are aimed at "penetrating" neighborhoods, replacing traditional practices of order-keeping with forms of state surveillance. In contrast, traditional institutions like the ronda (neighborhood watches), as well as the activities of local strongmen and preman, are based on "territorial relationships." ${ }^{28}$ In this framework, the state syariah system in Aceh is an example of surveillance. Like in Bandung, however, state power is limited by local claims to territoriality and associated performances of authority. This may be kept in mind as we move, in the following sections, towards a more grounded perspective of vigilante violence in Aceh.

\section{Conflict, Shifting Discourses, and the Politics of Public Morality in Aceh}

Discourse about public morality in Aceh often is connected to the perceived responsibility of the state in protecting the region's "strong" Islamic identity. According to official statistics, 98 percent of Aceh's circa four million inhabitants consider themselves to be Muslim, with a large majority being ethnically Acehnese. Historically, Islam has played an important role in the development of Acehnese self-

${ }^{25}$ Gerry van Klinken has focused on geography and economic interests as interrelated explanatory factors for political violence in Indonesia. See Gerry van Klinken, Communal Violence and Democratization in Indonesia: Small Town Wars (London: Routledge, 2007). As far as I know, however, there are no similar studies that focus on the kinds of violence that are not (commonly viewed as) "political" in nature.

${ }^{26}$ Bridget Welsh, "Local and National: Lynch Mobs in Indonesia," in Varshney, Collective Violence in Indonesia.

${ }^{27}$ Joshua Barker, "Surveillance and Territoriality in Bandung," in Figures of Criminality in Indonesia, the Philippines, and Colonial Vietnam, ed. Vicente L. Rafael (Ithaca, NY: Cornell Southeast Asia Program Publications, 1999).

${ }^{28}$ For another discussion of the practices and culture of the ronda, see James T. Siegel, Solo in the New Order: Language and Hierarchy in an Indonesian City (Princeton, NJ: Princeton University Press), pp. 39-43. 
consciousness and emerging nationalism, from the "Holy War" against Dutch colonial domination (1873-1942) to the emergence of the separatist rebellion waged by the ethno-nationalist Gerakan Aceh Merdeka (GAM, Aceh Independence Movement) (1976-2005). Both in the early years of the Indonesian republic and during the years following the collapse of the New Order-periods in which the relationship with Jakarta was redefined-contestations emerged within Aceh about the questions regarding what status should be given to Islamic law, what interpretation of the law should be followed, and who should have the formal authority to make those decisions. It is important, therefore, to give an overview of these historical trajectories, and to ask how the current implementation of syariah both builds on and departs from earlier state interventions, and how local contestations complicate the standard narrative of political Islam in Aceh.

The first governor of Aceh after 1945, Daud Beureueh, was a reform-minded ulama (religious teacher) who aspired to create a "truly Islamic" polity in Aceh. ${ }^{29} \mathrm{His}$ government attempted to establish a system of Islamic (syariah) courts, which was to be placed under the control of the ulama and function autonomously from the central government. ${ }^{30}$ The rise to power of reformist ulama was contested, however, and ultimately the attempts to Islamize the political and juridical system failed, partly because of the lack of support from local elites. The latter included conservative religious teachers, who, like their counterparts in other parts of Muslim Southeast Asia, resisted the reformist movement's attacks on traditional religious practices and interpretations of the law. Disappointment among reformist ulama, in combination with a range of other social and economic factors, led to the outbreak of a rebellion under the banner of Darul Islam ("Abode of Islam," 1953-62). Central to this revolt was the idea of a "broken promise." According to Daud Beureueh, President Sukarno had promised him, in a personal conversation in 1947, that Aceh would be allowed to implement Islamic law. When, in 1951, the government decided to incorporate Aceh in the province of North Sumatra, nullifying most of its "Islamic" regulations, this was regarded as betrayal.

The Darul Islam insurgency was not designed to separate Aceh from Indonesia, but rather to make Indonesia as a whole an Islamic state, based on the primacy of syariah. ${ }^{31}$ The revolt was ended when the Indonesian government restored Acehnese autonomy in matters of religion, education, and customs. In 1962, Daud Beureueh gave up the struggle and retired from politics. Thereafter, the 1965 military coup heralded a period

\footnotetext{
${ }^{29}$ Daud Beureueh was the leader of the reformist Persatuan Ulama-Ulama Seluruh Aceh (PUSA, AllAcehnese Association of Ulama). This movement became rather powerful during the Japanese occupation, particularly in the domain of Islamic law, which used to be the jurisdiction of the traditional aristocracy (the uleebalang). After the Japanese surrendered, the tension between these two groups erupted into a violent struggle for power known as the Social Revolution (1945-46). In this brief but intense confrontation, the uleebalang were stripped of power. Many were killed or incarcerated. In subsequent years, reformist ulama obtained important positions in the provincial government. For a detailed discussion of this period, see Anthony J. S. Reid, The Blood of the People: Revolution and the End of Traditional Rule in Northern Sumatra (Kuala Lumpur: Oxford University Press, 1979).

${ }^{30}$ See Eric E. Morris, "Islam and Politics in Aceh: a Study of Center-periphery Relations in Indonesia" (PhD dissertation, Cornell University, 1983), pp. 162-63.

${ }^{31}$ For discussions of this period, see Kees van Dijk, Rebellion under the Banner of Islam: The Darul Islam in Indonesia (The Hague: Nijhoff, 1981); and Nazaruddin Sjamsuddin, The Republican Revolt: A Study of the Acehnese Rebellion (Singapore: Institute of Southeast Asian Studies, 1985).
} 
of strong administrative centralization and a concentration of power in Jakarta, while former Darul Islam supporters were transformed, gradually, from rebels into state agents. ${ }^{32}$ Islamic law was not a priority of the New Order regime and the ulama were increasingly co-opted or otherwise appeased by the government. ${ }^{33}$

In the early 1970s, large quantities of oil and natural gas were discovered off the coast of North Aceh. The central government's policy to appropriate these resources sowed the seed of a new conflict. In 1976, Hasan di Tiro-a grandson of a famous ulama, Teungku Cik di Tiro, who fought in the war against the Dutch-established Gerakan Aceh Merdeka. GAM came forth, at least partly, from Darul Islam. Unlike its predecessor, however, GAM was not primarily an Islamic movement. While Islam played a part in its ideology in the early years, in the 1980s and 1990s GAM developed a largely secular, ethno-nationalist discourse, directed at "restoring" Aceh to its precolonial position as an independent state. When, in 1999, Aceh province was allowed the implementation of an Islamic penal code as part of a broader autonomy package, the initiative was rejected by GAM as a move to deflect attention from the roots of the conflict, and to delegitimize the separatist movement in the eyes of the Acehnese people. ${ }^{34}$

The implementation of a state syariah legal framework was initiated in 2002-03, when Governor Abdulah Puteh issued a series of bylaws (qanun) regarding the regulation of creed (akhidah), worship (ibadah), and religious symbolism (syiar, a term commonly used for manners of conduct associated with the lives of the Prophet or saints), as well as the criminal persecution of the use of intoxicants (khamar), gambling (maisir), and illicit relations between men and women (khalwat). A set of newly created government institutions was given the task of enforcing and socializing these regulations, including (besides the already existing Islamic courts and the provincial Council of Religious Scholars, Majelis Permusyawaratan Ulama, or MPU), the State Syariah Agency and a syariah police force. ${ }^{35}$

In 2004, the Indian Ocean tsunami destroyed the provincial capital Banda Aceh and much of the west coast, and took an estimated 170,000 lives across the province. One year later, in August 2005, GAM signed a peace agreement with the Indonesian

\footnotetext{
${ }^{32}$ In the 1970s and 1980s, this group — which included many descendants of reformist ulama-became known as the "technocrats." See, for example, Edward Aspinall, Islam and Nation: Separatist Rebellion in Aceh, Indonesia (Stanford, CA: Stanford University Press, 2009), pp. 52-55; Tim Kell, The Roots of Acehnese Rebellion, 1989 -1992 (Ithaca, NY: Cornell Modern Indonesia Project, 1995), pp. 29-32; Morris, "Islam and Politics in Aceh," pp. 269-302; and Rodd McGibbon, "Local Leadership and the Aceh Conflict," in Verandah of Violence: Background to the Aceh Problem, ed. Anthony J. S. Reid (Singapore: NUS Press, 2006), pp. 315-59.

${ }^{33}$ See Aspinall, Islam and Nation, pp. 202-8.

${ }^{34}$ See Law no. 44/1999 on the Special Status of the Province of Aceh. For a discussion of the stance of, respectively, the GAM and the Indonesian government, see Aspinall, Islam and Nation; and Michelle A. Miller, Rebellion and Reform in Indonesia: Jakarta's Security and Autonomy Policies in Aceh (London: Routledge, 2009).

${ }^{35}$ For an elaborate discussion of these institutions, see Feener, Shari'a and Social Engineering. See also Moch Nur Ichwan, "Official Ulema and the Politics of Re-Islamization: The Majelis Permusyawaratan Ulama, Shari'atization, and Contested Authority in Post-New Order Aceh," Journal of Islamic Studies 22,2 (2011); Lindsey et al., "Shari'a Revival in Aceh," in Islamic Law in Contemporary Indonesia: Ideas and Institutions, ed. R. Michael Feener and Mark E. Cammack (Cambridge, MA: Harvard University Press, 2007); and Arskal Salim and Azyumardi Azra, Shari'a and Politics in Modern Indonesia (Singapore: ISEAS, 2003).
} 
government (the accord is commonly referred to as the Helsinki MoU ${ }^{36}$ ). As a result, the rebel movement was disarmed and turned into a political party, Partai Aceh (PA), which is currently in control of the government both at the provincial level and in most districts. So far, the stance of PA and many of its representatives toward the syariah legal system has been ambiguous. In some respects, the state syariah system has been further developed. In general, however, Aceh's new leaders have prioritized other issues, much to the dismay of pro-syariah advocates.

The implementation of state syariah has been viewed by some scholars as a reaction, on the side of the government and an aligned Acehnese elite, to the political crisis of the late $1990 \mathrm{~s} .{ }^{37}$ Indeed, some people, primarily from GAM or progressive activist circles, see the syariah legal framework as something that was forced on the Acehnese. Yet, the claim that the Acehnese formulation of syariah was "invented" in Jakarta ignores, firstly, the long and complex genealogy of the concept of Islamic law and its resonance in Acehnese society, and, secondly, the fact that the syariah legal system was built on the basis of a set of local discourses and institutions that has been decades in the making. ${ }^{38}$ In Aceh, the idea that the state has a leading role in guarding "correct" Islamic practices and public morality enjoys wide support. Yet, the question of how these new regulations should be drafted and enforced, and to what extent and on what legal basis the state should be allowed to interfere in local communities and private lives, has been passionately debated among religious leaders, in the provincial parliament, and at neighborhood coffee shops. ${ }^{39}$

A central concern in these debates is the position of the ulama. In Aceh, like in other parts of Indonesia, a broad distinction is made between (urban-based) ulama whose careers are defined by their involvement in state institutions (like the State Islamic Institute Ar-Raniry, the MPU, or state syariah institutions, such as the Dinas Syariat Islam) and the rural-based leaders (ulama dayah) of traditional religious boarding schools (called dayah or pesantren). Although generally supportive of the idea of strengthening the status of Islamic law, many ulama dayah have been hesitant, for political as well as ideological reasons, to get closely involved in the state syariah

\footnotetext{
${ }^{36}$ Officially, the "Memorandum of Understanding between the Government of the Republic of Indonesia and the Free Aceh Movement."

${ }^{37}$ See, for example, Aspinall, Islam and Nation, pp. 156-49.

${ }^{38}$ According to Michael Feener, administrators in Aceh have worked on an ambitious and progressive state project directed at the cultivation of a syariah-minded ethics since the 1960s. The "Shari'a project" was designed by teachers and scholars affiliated with state institutions such as the IAIN (Institut Agama Islam Negeri, State Institute for Islamic Studies) Ar-Raniry (founded 1960) and the Ulama Council (the predecessor of the MPU, founded in 1966). It was instrumental in the process of aligning Acehnese ulama with the central ideological principles of the New Order by molding Islamic norms and practices (and their scriptural justification) in the straitjacket of security and economic growth. In Feener's view, syariah is part and parcel of a general government strategy of Islamizing the state, a process tuned to the changing lifestyles of the conservative segment of the urban middle class, one of the regime's most loyal constituencies. See Feener, Shari'a and Social Engineering, particularly pp. 37-47.

${ }^{39}$ For discussions taking place in the public sphere, see Feener, Shari'a and Social Engineering, pp. $216-49$. For ethnographic discussions of the impact of state syariah on Acehnese society and the lives of ordinary Acehnese, see David Kloos, "Becoming Better Muslims: Religious Authority and Ethical Improvement in Aceh, Indonesia" (PhD dissertation, VU University Amsterdam, 2013); and R. Michael Feener, David Kloos, and Annemarie Samuels, eds., Islam and the Limits of the State: Reconfigurations of Practice, Community, and Authority in Contemporary Aceh, Indonesia (Leiden: Brill, forthcoming).
} 
project. ${ }^{40} \mathrm{I}$ will discuss the role of religious leaders in more detail in subsequent sections. The remainder of this section serves to look beyond the domains of formal politics and religious institutions, and takes into account some of the broader developments and shifting discourses that inform the local dynamics of morality policing in Aceh.

Recent calls for a vigorous enforcement of scriptural Islamic norms must be viewed in the context of post-conflict, post-disaster reconstruction and reconciliation. The conflict was experienced by many Acehnese as a period of profound lawlessness. In some respects, the implementation of syariah has been viewed as a way to reinstate a sense of justice where secular law has failed. Adding to this dynamic, the 2004 tsunami and its aftermath have driven the issue of public morality, rather forcefully, to the forefront of debates about the future of Aceh. It is common discourse, among both administrators and ordinary people, that the tsunami was a "warning" (peringatan), a "test" (percobaan), or even a "punishment" for the sinful behavior of the Acehnese. Prosyariah activists have elaborated on this view, for example, by arguing that the postconflict, post-tsunami situation offers an unprecedented opportunity for bringing Aceh back to its "true" Islamic identity. ${ }^{41}$ Public discussions of vigilante violence, as a legitimate way for local communities to cleanse their villages and neighborhoods from sinful behavior, is often framed in this discourse.

Particularly important, with regard to the dissemination and intensification of these discourses, is the role of the media, both print and electronic. Reports of morality policing commonly blame victims rather than the perpetrators of the violence. ${ }^{42}$ Newspapers, including the largest and most widely distributed local daily in Aceh, Serambi Indonesia, often report in detail about "sinful acts," while joining in with the practice of public shaming by publishing the names and residence of those who are caught and punished. Reporters actively seek sensational stories by making use of their contacts within the police and the $\mathrm{WH}$, who in turn have stakes in sharing this information. ${ }^{43}$ Journalists are generally not interested in identifying the mobilizing agents in the outbreak of mass violence. Instead, instances of citizens taking the law into their own hands are framed as "people running amok" (masyarakat mangamuk) or as the outbreak of "anarchy" (sudah jadi anarki), implying spontaneity rather than organized violence. An interesting development, in this respect, is the increasingly stark competition between (self-declared) "pro-syariah" journalists and journalists who

\footnotetext{
${ }^{40}$ Many ulama in Aceh uphold an ambiguous relationship with the state, as they try to strike a balance between securing government support and maintaining institutional independence. By "doctrinal reasons" I mean that the content of state syariah diverges in a number of important aspects from more traditionalist (or "classical") interpretations of Islamic law.

${ }^{41}$ For an elaborate discussion of these debates, focusing on the tensions and interactions between the different temporalities associated with post-tsunami reconstruction, "development," and the moral uplifting of state and society through the implementation of syariah, see Annemarie Samuels, "Hikmah and Narratives of Change: How Different Temporalities Shape the Present and the Future in Post-tsunami Aceh," in Feener et. al., Islam and the Limits of the State.

${ }^{42}$ Sarah J. Newman, "Patrolling Sexuality: A Case Study on Khalwat and Vigilantism in Aceh," paper presented at the second ICAIOS (International Centre for Aceh and Indian Ocean Studies) conference, Banda Aceh, February 23-24, 2009.

${ }^{43}$ See, for example, Benjamin Otto and Jan-Michiel Otto, "Practices and Perceptions of Syariah Reinforcement in Banda Aceh: The Wilayatul Hisbah and Local Communities," in Feener et. al., Islam and the Limits of the State.
} 
are (implicitly or explicitly) accused of taking a "soft" line in matters of Islamic morality. ${ }^{44}$ As we shall see in the case studies below, politicians and other actors with stakes in the process of syariah implementation capitalize on this form of polarization.

In contrast, the responses of ordinary Acehnese to the changes wrought on Aceh after the tsunami take a more ambivalent form. Many of my interlocutors were simultaneously enthusiastic and worried about the ways in which Aceh had been "opened up" (sudah terbuka) by the tsunami and the end of the conflict. While they were often optimistic about the new opportunities promised by these developments, they often expressed mixed feelings about the impact on society of "outside" influences. ${ }^{45}$ Of course, these effects are not found in equal measure throughout Aceh. In places that were affected most directly by the tsunami, the sense of loss was accompanied by significant social and physical changes, including the arrival of many "newcomers" (pendatang). This influx includes relatively "risky" categories from a public morality point of view, such as transient single people (young men and women looking for jobs, students), but also members of the state security services (police, military, and intelligence), commonly glossed by ordinary villagers as aparat (the "apparatus"). In such places it seems less clear than in the past who owns what house, who lives where and for how long, and, more generally, "what is going on." At the same time, increasing mobility is a more general feature of the post-conflict era. Military checkpoints, road blocks, and other obstacles to traveling have largely disappeared. With many households owning at least one or two motorcycles, people increasingly work and study away from home. These changes, together with a sharp increase in the use of internet and mobile communication, contribute to an atmosphere in which news, rumors, distorted truths, and calls for action travel faster than before. As I will show in the cases below, these changes influence the ways in which local actors define and act upon local "rules of conduct." Before we move there, however, it is important to have a clear picture of morality policing in Aceh, in relation both to the implementation of syariah and the social construction of village "territories."

\section{In the Name of Syariah?}

As we have seen in the previous section, the framework of state syariah reflects a relatively coherent political and ideological agenda, intended to transform Acehnese society on the basis of a scripturalist understanding of Islamic norms, and advanced and supported primarily by a conservative urban elite and a large cross-section of ulama. However, as a more general means to represent practices and attitudes, including vigilante action, the syariah label has an older, more diffuse history. While syariah was a concern of the state in the 1950s and again since 1999, the concept has also functioned throughout the twentieth century as a motivation for vigilantes. Particular

\footnotetext{
${ }^{44}$ A conspicuous example is the announcement, on December 13, 2012, of the "Kaukus Wartawan Peduli Syariat Islam" (Assembly of Journalists Who Care about Syariah), which received support from the government and from ulama associations. See "Wartawan Gagas Kaukus Pembela Syariat," Serambi Indonesia, September 23, 2012; "Ulama dan Pemerintah Aceh Dukung Kaukus Syariat," Serambi Indonesia, September 24, 2012; and "Kaukus Wartawan Peduli Syariat Dideklarasikan," Serambi Indonesia, December 13, 2012.

${ }^{45}$ For more elaborate discussions, see Kloos, "Becoming Better Muslims," and Annemarie Samuels, "After the Tsunami: The Remaking of Everyday Life in Banda Aceh, Indonesia" (PhD dissertation, Leiden University, 2012).
} 
to the recent period, then, is that different groups and individuals have engaged, explicitly, in attempts to "assist" the state in enforcing Islamic law. At the same time, not all actions in defense of public morality are connected to the state syariah system. Central, in this respect, are the territorial practices and discourses associated with the concept of adat (or customary) law. In order to assess why, and on what basis, different actors have come to label, or re-label, vigilante practices as either "syariah" or "adat," it is important to consider, in the first place, the context of the conflict.

In the late 1980s, students of Teungku Bantaqiah, a charismatic religious teacher from Beutong Ateuh, West Aceh, were known for patrolling the roads in their area in an attempt to bring people "back to syariah." In one incident mentioned in the literature, a Chinese Indonesian was killed for refusing to close his restaurant during the fasting month. Teungku Bantaqiah was widely believed to possess magical knowledge and associated skills of self-defense (ilmu kebal), and in 1987 the Ulama Council declared his teachings deviant. ${ }^{46}$ In a comparable case, students of Teungku Ahmed Dewi, an ulama from Bantayan Idi Cut, East Aceh, chased away young, unmarried couples from the beach. ${ }^{47}$ Both ulama were accused by the government of cooperating with GAM. In 1999, Teungku Bantaqiah and fifty-six of his students were killed in "one of the more notorious military massacres of 1999." 48

In 1999, shortly after the announcement of the "Autonomy Law" (Indonesia's Regulation 44/1999, which formalized the opportunity for Aceh to apply Islamic law), reports appeared in local newspapers about "headscarf raids" (razia jilbab). In one reported incident, a group of masked men stopped a bus of female factory workers in Langsa (East Aceh). Seven women were ordered to get off the bus, after which they had their hair cut and heads shaven. In response to these disturbing incidents, the local women's rights organization Flower Aceh sounded the alarm, alerting "all parties" that this violence should stop immediately..$^{49}$ As suddenly as the problem emerged, the harassment stopped again by the end of 1999. Although the perpetrators were never identified, it was widely speculated that they were TNI (Tentara Nasional Indonesia, Indonesian Armed Forces) elements pretending to be GAM, in order to give the separatists a bad name. GAM spokespeople quickly distanced themselves from the raids. In contrast, representatives of formal authority in Aceh (e.g., state administrators and ulama), as well as most opinion makers, remained conspicuously silent about the raids, to the great dissatisfaction of human rights and women's rights activists. ${ }^{50}$

\footnotetext{
${ }^{46}$ Teungku Bantaqiah and his students were known as the "white robes" movement (Jubah Putih). See Dyah Rahmany, Matinya Bantaqiah: Menguak Tragedi Beutong Ateuh (Jakarta: Lembaga Studi Pers dan Pembangunan, 2001); Leon Jones, "The Security Disturbances in Aceh during 1990" (working paper, Centre for Southeast Asian Studies, Monash University, 1990), pp. 10-11; and Otto Syamsuddin Ishak, Sang martir: Teungku Bantaqiah (Jakarta: Yappika, 2003).

${ }^{47}$ Mahdi Syihab, "Penegakan Syariat: Etnografi aksi razia santri dayah di aceh utara," in Serambi Mekkah yang Berubah: Views from Within, ed. Arskal Salim and Adlin Sila (Tangerang: Pustaka Alvabet and Aceh Research Training Institute, 2010), pp. 60-61. Reportedly, many of Teungku Bantaqiah's students were self-declared former "sinners," who regarded their participation in these raids as a form of personal repentance.

${ }^{48}$ Aspinall, Islam and Nation, p. 99.

49 "Hentikan kekerasan dalam razia jilbab di Aceh; di Aceh Timur tujuh wanita digunduli," Serambi Indonesia, September 18, 1999.

${ }^{50}$ Jacqueline Siapno, who carried out fieldwork in Aceh in the 1990s, was told by one of her female interlocutors that this silence was "perceived by women as condoning street harassment against women." In some cases, the violence was even explicitly endorsed. A (male) journalist reportedly stated that "[i]t is
} 
If the 1999 headscarf raids seem to be directly related to the conflict, the postconflict years have seen more, rather than fewer, examples of non-state violence carried out "in the name of syariah." Many of these incidents are hardly covert. They take place openly, often with the consent (implicit or explicit) of local authorities. In 2006, a group of young Banda Aceh residents calling itself Tim Anti-Maksiat (TAM, Anti-Sin Team) began to patrol areas in and around the city, including the popular beach at Lhoknga. At the beach, they "arrested" unmarried couples, after which they alerted the WH to further "process" those cases. According to its members, the initiative was motivated by the wish to "uphold" syariah throughout Aceh. ${ }^{51}$ A similar, more forceful initiative is the Badan Anti-Maksiat (BAM, Anti-Sin League), founded in August 2006 by Fakhruddin bin Hasjmi. This organization, which claimed an active membership of three hundred, has carried out raids at beauty salons suspected of being brothels and coffee shops where gambling was thought to be taking place, and against "indecently dressed" women on the street. Far from being isolated, the BAM upholds excellent contacts with the police, the WH, the Ulama Council, the local government, the State Syariah Agency, and the leaders of traditional religious boarding schools. It has even received funding from the government, and has been allowed to join the WH during its operations. In an interview with Michael Feener, Fakhruddin described his movement as "helping the state in the effort to implement the Sharita in Aceh." ${ }^{52}$

The operations carried out by the Badan Anti Maksiat are similar to those of the radically Islamist Front Pembelaan Islam (FPI, Islamic Defenders Front), a paramilitary group infamous for its violent sweepings of bars and brothels in big cities, attacks on religious and gender minority groups, and close ties to the police force and military. ${ }^{53}$ The FPI established a branch in Aceh in 2008, but so far its actions have been much less extensive and disruptive than in other parts of Indonesia, perhaps because of its ties to the military. While some religious leaders have shown signs of sympathy for the movement, motivated by the view that the GAM-dominated provincial government has not done enough to enforce Islamic law, support for the FPI seems, in general, to be marginal. ${ }^{54}$ Potentially more destabilizing is the phenomenon of ex-GAM combatants who, feeling excluded from the privileges and opportunities flowing from the peace process, have framed their struggle in religious terms. In at least one case, this led to a short-lived and rather shady alliance with the FPI. ${ }^{55}$

a good thing that someone is forcing [women] to veil. We have been trying to conduct a socialization program for veiling since 1995 and have been unsuccessful. So it is a good thing that society is now forcing them to do so-if not they will never veil." Jacqueline A. Siapno, Gender, Islam, Nationalism, and the State in Aceh: The Paradox of Pozver, Co-optation, and Resistance (London: RoutledgeCurzon, 2002), pp. 37-38.

${ }^{51}$ International Crisis Group, "Islamic Law and Criminal Justice in Aceh," pp. 9-10. It is unclear from this report how, and by whom, these people were mobilized.

${ }^{52}$ See Feener, Shari'a and Social Engineering, p. 241.

${ }^{53}$ See Chaider S. Bamualim, "Islamic Militancy and Resentment against Hadramis in Post-Suharto Indonesia: A Case Study of Habib Rizieq Syihab and his Islamic Defenders Front," Comparative Studies of South Asia, Africa, and the Middle East 31,2 (2011).

${ }^{54}$ Marzi Afriko, "Syariat Islam dan radikalisme massa: Melacak jejak awal kehadiran FPI di Aceh," in Serambi Mekkah yang Berubah, ed. Arskal Salim and Adlin Sila, pp. 19-56.

55 The so-called Pasukan Peudeung (Sword Force) consisted of followers of Teungku Badruddin, an ulama and ex-GAM commander from Sawang, North Aceh, who rejected the Helsinki MoU and turned against the Komite Peralihan Aceh (KPA, Aceh Transitional Committee, the civilian organization of ex-GAM 
In order to analyze the connections between vigilantism and ideas about and expressions of "territory," it is helpful to consider the broader history of the relation between syariah and adat in the Acehnese context. The preceding paragraphs have made it clear that vigilantes of different backgrounds have claimed to defend, or properly enforce, Islamic law. For some, like Teungku Bantaqiah, ideological motivations may have been paramount. For others, like the mysterious perpetrators of the 1999 "raziah jilbab," the term "syariah" seems to have served primarily as a means for escalating the political situation. More important, in terms of popular support, is the stance of the majority of ulama dayah. Most ulama seem to be supportive of state syariah, not just because of the perceived need to "clear" Aceh from sinful behavior, but also because of the possibilities it offers for elevating the ulama's political status. Different ulama associations have been involved in the process of drafting specific syariah regulations, and in a few cases, dayah leaders disappointed with the way in which the new laws have been enforced have mobilized their students to "assist" the state by carrying out intimidating raids in the close vicinity of the dayah. ${ }^{56}$

Often, however, the defense of public morality is not, or not primarily, related to state syariah. An alternative framework is constituted by the local, ethnically or territorially based hybrid structures of moral values, customs, and institutions typically glossed as adat. While syariah-centered discourses are typically outwardlooking, directed at the integration of Aceh in the wider Muslim world, adat-centered discourses are tied to the conceptualization of the village as a distinct moral sphere, evoking powerful notions of territoriality. Claims to adat complicate the syariah "label," for they may be used both to reinforce, and contest, syariah-based notions of public morality.

In Aceh, more than in other Indonesian regions (with the exception, perhaps, of West Sumatra), the concept of "Islamic law" has been highly politicized since the colonial period. In the late nineteenth century, Acehnese resistance against Dutch colonialism was dominated by a group of militant ulama, who framed the struggle as a "Holy War." In response, and relying partially on the work of orientalist scholars such as Christiaan Snouck Hurgronje, Dutch administrators began to distinguish, forcefully but also rather artificially, between a "universal" Islamic code of law and local customs and traditions. ${ }^{57} \mathrm{By}$ the time the Dutch were in control of the largest part of Aceh, from

combatants). Teungku Badruddin, who was held responsible for a wave of conspicuous criminal acts in mid-2007, was killed in December of the same year by a commando unit of heavily armed men. The killing set in motion a brief, but highly disturbing, spree of kidnappings and shootings in the North Aceh district. The Sword Force, which combined the ethno-nationalist discourse of GAM with a radical jihadi ideology, became infamous for extorting and intimidating local NGOs as well as harassing "improperly dressed" women. See The World Bank, "Aceh Conflict Monitoring Update," August-December 2007; and Jesse H. Grayman, Community Perceptions of the Peace Process: Eleven Case Studies for the Multi-Stakeholder Review of Post-Conflict Programming in Aceh (MSR) (Jakarta: The World Bank, 2009). Cf. Bobby Anderson, "Gangster, Ideologue, Martyr: The Posthumous Reinvention of Teungku Badruddin and the Nature of the Free Aceh Movement," Conflict, Security, and Development 13,1 (2013).

${ }^{56}$ Mahdi Syahib, "Penegakan Syariat: Etnografi aksi razia santri," pp. 57-92. Radicalization among young ulama has been a point of concern. So far, however, attempts by radical jihadists to involve Acehnese ulama in their struggle have failed. See, for example, International Crisis Group, "Indonesia: Jihadi Surprise in Aceh," Asia Report No. 189 (April 2010).

${ }^{57}$ According to Snouck Hurgronje, many ulama were frustrated about the lack of interest shown by lay Acehnese in the "proper rules" of Islam. In his explanation for this, he cited the adherence to Islam and adat as a joint "foundation for Acehnese life." The Acehnese, he argued, saw Islam and adat as

"inseparable" systems. In practice, however, they did not hold Islamic law very highly, for adat often 
the late 1910s onwards, they continued to regard the ulama, categorically, as a potentially dangerous subversive force. In contrast, the place-specific forms of authority categorized as adat were formally recognized by the colonial state, and made into the exclusive prerogative of the uleebalang, the traditional Acehnese aristocracy.

From the 1930s onwards, reform-minded ulama sought to harmonize Acehnese conceptions of adat, as expressed in the tradition of matrilocality and gendered aspects of family and village life, with a modernist emphasis on law, discipline, and scriptural obligations (ibadah).$^{58}$ In 1945-46, a social revolution stripped the uleebalang of its power, causing a sudden delegitimization of adat as a source of political authority. In the second half of the twentieth century, the notion of adat was further depoliticized. While this was a general development, taking place throughout Indonesia, Aceh's history of rebellion made the official celebration of ethnic identity seem particularly important to the national and regional government. In the view of administrators in Jakarta and Banda Aceh, the region's "specialness" was to be simultaneously emphasized and politically neutralized in order to prevent future trouble. ${ }^{59}$ Beyond the domain of formal politics, however, adat remained an important source of moral authority at the village level, evident in the continuation of traditions of matrilocality, gender segregation, social control, and conflict resolution.

Just like Snouck Hurgronje's interlocutors more than a century ago, people today think of Islam and adat as complementary, rather than conflicting, traditions. As we shall see, however, a rather clear distinction is often made between syariah- and adatbased approaches to moral transgression. Besides references to secular law (typically glossed as "state law," hukum negara) and Islamic law (hukum Islam, or hukum Syariat), it is common to refer to customary law (hukum adat), or "village law" (hukum kampung), as a legitimate framework for addressing and enforcing social norms. Adat-based approaches to local conflicts often are explicitly non-violent, being directed at consultation (musyazarah), peace-making rituals (perdamaian), public apologies, ritual meals (kenduri), fines (det), and a general emphasis on preventing discord (fitnah) and revenge (dendam). At the same time, the use of violence, and the perceived right to carry out punishment without consulting village institutions, has been a part of village life for a long time, especially in the context of perceived breaches of sexual morality and resulting shameful situations. ${ }^{60}$

turned out to be the "mistress" and religious law "her submissive slave." Analytically, Snouck Hurgronje thus distinguished sharply between adat and Islamic orthodoxy as inherently opposing frameworks. Christiaan Snouck Hurgronje, De Atjehers, vol. I (Batavia: Landsdrukkerij, 1893-95), pp. 68, 74, 168.

${ }^{58}$ See James T. Siegel, The Rope of God (Ann Arbor, MI: University of Michigan Press, 2000 [1969]). According to Siegel, reformists turned to Acehnese perceptions of masculinity, which placed the development of "reason" ( $\mathrm{akal}$ ) in specifically male rites of passage, such as the departure from the family house after puberty, religious study in the pesantren, and the practice of merantau (long-term sojourn away from home for purposes of work or education) in order to reconcile modernist ideas with Acehnese cultural practices.

${ }^{59}$ For Aceh's technocratic administrators, adat came to stand for local expressions of dance, art and craft, local cuisine, and the specific form of traditional practices, such as weddings. Official efforts to glorify Acehnese history and culture were informed not just by the (general) attempt of the New Order to separate ethnicity and politics, but were also explicitly designed to "weave Aceh's historical narrative into that of Indonesia." Aspinall, Islam and Nation, pp. 35-38.

${ }^{60}$ See, for example, T. Bachtiar E. Panglima Polem, "Pengendalian social di Aceh Besar," in Segi-segi Social Budaya Masyarakat Aceh: Hasil-hasil Penelitian dengan Metode "Grounded Research," ed. Alfian (Jakarta:LP3ES, 1977), pp. 108-12. 
When ordinary Acehnese cite adat as a basis for action, this is often a conscious choice to exert their agency vis-à-vis the state, revealing a lack of trust in state institutions (including those of the syariah legal framework), as well as the fact that official legal procedures are generally regarded as costly and tedious. ${ }^{61}$ It would be wrong, however, to speak of a clear-cut struggle between the state and local communities. In recent decades, besides a "religious revival," a "revival of tradition" has taken place, noticeable in the increase of political claims related to ethnic or regional identities and loyalties. ${ }^{62}$ The state has played an active role in this development. While the syariah legal framework constitutes a significant extension of the state disciplinary apparatus, institutions of law enforcement have also, increasingly, it seems, encouraged local communities to solve local conflicts "between themselves," on the basis of adat law. ${ }^{63}$ In 2006, the provincial government established the Majelis Adat Aceh (MAA, Aceh Adat Council), an advisory council, which, among other things, has reinstated "traditional" Acehnese institutions, promoted Acehnese language and cultural traditions, and sent its representatives to villages in order to explain and "socialize" traditional norms and values. In 2008, and in cooperation with the UNDP (United Nations Development Program), the MAA published a practical "guide" in adat law, intended to help local leaders carry out their role "justly, responsibly, and effectively." ${ }^{64}$ While the MAA has emphasized the consistency of local customs and Islamic law, the adat revival shows that state discourses of public morality do not revolve solely around the notion of syariah.

The definition and enforcement of local norms is contested, and depends on the extent to which community leaders, ordinary citizens, and state institutions are able to cooperate and come up with shared conceptions of security, stability, and law enforcement. Questions of territoriality take center stage in these debates. In the next section I discuss a number of concrete case studies that show how, and under what kind of circumstances, contestations about territory and associated concerns of public morality can result in violence. The cases indicate an engagement of ordinary villagers and state agents in the everyday contestations about moral authority and public space in present-day Aceh. They show that violent incidents, more than just the outbursts of emotion or anger related to a perceived infringement of religious norms, are part and parcel of the social construction of places and reputations.

\footnotetext{
${ }^{61}$ Often, it is stated that it is not necessary to involve the police or the (secular or Islamic) court as long as it is possible to deal with the matter "by means of adat" (secara adat or melalui adat). See also the UNDP Indonesia dan Badan Rekonstruksi dan Rehabilitasi (BRR) report, "Access to Justice in Aceh: Making the Transition to Sustainable Peace and Development in Aceh," 2006, p. 79. Benjamin Otto and Jan-Michiel Otto, in a forthcoming article, show that the role of the Wilayatul Hisbah in enforcing syariah is often limited to the extent that local communities are willing to cooperate with those police. See Otto and Otto, "Practices and Perceptions of Syariah Reinforcement in Banda Aceh."

${ }^{62}$ See, for example, Adriaan Bedner and Stijn van Huis, "The Return of the Native in Indonesian Law: Indigenous Communities in Indonesian Legislation," Bijdragen tot de Taal-, Land-, en Volkenkunde 164,2-3 (2008); Jamie S. Davidson and David Henley, eds., The Revival of Tradition in Indonesian Politics: The Deployment of Adat from Colonialism to Indigenism (London and New York, NY: Routledge, 2007); Tania M. $\mathrm{Li}$, The Will to Improve: Governmentality, Development, and the Practice of Politics (Durham, NC: Duke University Press, 2007); and Henk Schulte Nordholt and Gerry van Klinken, eds., Renegotiating Boundaries: Local Politics in Post-Suharto Indonesia (Leiden: KITLV Press, 2007).

${ }^{63}$ This results, at least partly, from the peace process, which has required security forces to change their attitude toward local communities. I will return to this development in some more detail at the end of the fourth section.

${ }^{64}$ Majelis Adat Aceh, Pedoman Peradilan Adat di Aceh (2008), p. 3.
} 


\section{Places and Reputations: Cases of Violence}

The cases below report on different kinds of violence. I will deal, in turn, with cases of mob violence directed against so-called "deviant" teachings, local youth claiming to protect the "good name" of their village, and the activities of an ambitious politician interfering in a controversy over public space. Regarded separately, these cases provide insight into the variety of different motivations that contribute to the local outbreak of vigilante action. Seen together, they reveal a more general pattern pertaining to the interrelated dynamics of morality policing, state practice and the social construction of locality.

\section{The Criminalization of "Deviancy": The Cases of Teungku Aiyub and Mirza Alfath}

In April 2011, Governor Irwandi Yusuf issued a press statement in which he announced a formal ban (in the form of a Peraturan Gubernor, "Governor Decree") of fourteen "deviant sects" (aliran sesat). This decision was made after the government of Aceh, with the assistance of the MPU, had investigated the practices and doctrines allegedly disseminated by seventeen non-mainstream groups. ${ }^{65}$ While it is possible to speculate about Irwandi's motives (up until that point he had rarely expressed an interest in such matters, and it is very possible that this was a strategy to attract and increase support among conservative religious leaders), there is no question that such regulations resonated with fears and tensions within Acehnese society about fringe groups trying to lead Acehnese Muslims "astray."

In part, the sensitivity associated with alleged "deviant sects" may be seen as a continuation of New Order discourses concerned with "correct religion." It is also, however, rooted in an older, more place-specific discourse tied to the need to keep Aceh "clean" from harmful "outside" influences. As we have seen, the "opening up" of Aceh after the 2004 tsunami, and the subsequent ending of the separatist conflict, has led to moral anxieties, which are easily capitalized on by political actors, particularly those with a flair for populism. Two recent cases have sparked particular concern, inside and outside Aceh. The first deals with the murder of a religious teacher accused of deviancy in the district of Bireuen, the second with the near-lynching (and subsequent arrest) of a university lecturer accused of insulting Islam in the city of Lhokseumawe. I will discuss both cases briefly and in turn.

In November 2012, a religious teacher known as Teungku Aiyub, a resident of the subdistrict of Plimbang, Bireuen (on the North coast of Aceh province), was killed by an angry mob. During the clash, one of his students and one of his attackers were also killed. Ten people were seriously injured. While various versions of the story circulate, the general picture is as follows. On the night of November 17, a group of some dozen people approached the house of Teungku Aiyub, who at that moment was giving his weekly religious lesson. Teungku Aiyub's group surprised the visitors by coming out of the house and attacking them with swords and machetes. The mob fled, only to return with many hundreds more. In the meantime, most of Teungku Aiyub's followers had fled from the location, leaving behind only three, including Teungku Aiyub himself. Police and military officers arrived at the scene after the initial

65 "Pemerintah Aceh Larang 14 Aliran Keagamaan," Serambi Indonesia, A pril 7, 2011. 
disturbance. However, when the mob returned, the police did not, or could not, prevent the murder of Teungku Aiyub. His house was burned to the ground. The leader of the accused "sect" and one of his students were shot and also burned, apparently before the eyes of the police. ${ }^{66}$

By the time of the clash, the controversy around Teungku Aiyub had been dragging on for almost two years-a period in which the group was regularly accused of adhering to deviant teachings. According to villagers, the teacher claimed that the places of worship in the village were "not pure," while his followers were prohibited from following the imam (village religious leader) in prayer. Villagers were also concerned about the lessons taught by Teungku Aiyub about death-related rituals. ${ }^{67}$ Finally, there were all kinds of rumors of sexual transgressions being part of the "mysterious" meetings in the teacher's house. Unsurprisingly, the case of Teungku Aiyub sparked concern among local human rights groups. A KontraS spokesperson issued a statement in which he called on all parties involved to "respect the supremacy of the law and not to take the law into one's own hands." In addition, he requested that the police seriously investigate the case in order to prevent such outbreaks in the future. ${ }^{68}$ According to the district head (bupati), Ruslan M. Daud, an officer from the United Nations even came to the village to investigate the case. ${ }^{69}$

The second case concerns Mirza Alfath, a lecturer at the Law Faculty of the Universitas Malikussaleh, in the city of Lhokseumawe (also on the North coast). On November 20, 2012, Mirza was accused, via an article in the largest provincial newspaper, Serambi Indonesia, of "insulting" Islam and "glorifying Jews" on his Facebook page. ${ }^{70}$ On the same night, a large mob (consisting of "hundreds" of people, according to most media reports) gathered in front of his house. Soon thereafter, people started throwing rocks at the house. ${ }^{71}$ Before the situation escalated further, the police arrived on the scene, closed off the property, and brought Mirza Alfath "into safety" at the police station. In subsequent days, Mirza was questioned by the police and by members of the local (Lhokseumawe) branch of the MPU. The council showed particular interest in two accusations that raised questions about Mirza, that is, whether he was an "atheist" and whether he was a supporter of Israeli policies with regard to the Palestine conflict. ${ }^{72}$ Mirza responded that he had not been understood

${ }^{66}$ See, for example, "Malam berdarah di Jambo Dalam," Modus Aceh, November 19-25, 2012; "Inilah Kronologis Bentrokan Warga Dengan Kelompok Tgk Aiyub," November 17, 2012, http: / / wartaaceh.com/ inilah-kronologis-bentrokan-warga-dengan-kelompok-tgk-aiyub/, accessed July 29, 2014; and "Balai Pengajian Diamuk Massa, 3 Tewas dan 9 Luka," November 17, 2012, http: / / www.acehkita.com/ berita/ balai-pengajian-diamuk-massa-3-tewas-dan-10-luka/, accessed July 29, 2014.

67 "Malam berdarah di Jambo Dalam."

68 "KontraS Ajak Semua Pihak Hormati Hukum," Acehkita.com, November 19, 2012, http:/ / www. acehkita.com/ berita/ kontras-ajak-semua-pihak-hormati-hukum/, accessed July 29, 2014.

69 “Buntut Bentrokan Plimbang; Bupati Bilang Petugas PBB Akan Turun ke Bireuen,” December 5, 2012, Atjehpost.com, http:/ / atjehpost.com/read/2012/12/05/30398/15/5/Buntut-Bentrokan-PlimbangBupati-Bilang-Petugas-PBB-Akan-Turun-ke-Bireuen, accessed December 29, 2012.

${ }^{70}$ Teuku Zulkhairi, "Akun Facebook 'Mirza Alfaths' Menghina Islam," Serambi Indonesia, November 20, 2012.

71 "Mirza terjaring di jaring Facebook," Modus Aceh, November 26-December 2, 2012.

72 "Dibalik pertemuan Mirza dengan MPU," Modus Aceh, November 26-December 2, 2012. In one Facebook posting, Mirza had written that "God is the most creative product of human imagination" (Tuhan itu produk imajinasi manusia yang paling kreatif). 
correctly, that the nature of his postings was "academic" rather than a reflection of his own opinions, and that he had been quoting others in order to raise a debate. On the basis of these "interrogations," the MPU concluded that Mirza's Facebook postings were "off the mark" (sudah jelas melenceng) and that Mirza was willing to repent for his writings. On Friday, November 23, in the presence of a congregation at the Islamic Centre Mosque in Lhokseumawe, Mirza publicly admitted his mistake. He asked the Islamic community, the Acehnese community, the people of Lhokseumawe, his neighbors, and his Facebook network to forgive him for postings that "were considered insulting and harmful to Islam." In addition, he confirmed his adherence to Islam by pronouncing the confession of faith (syahadat).$^{73} \mathrm{He}$ also promised to leave his residence in Keude.

\section{Protecting the Good Name of the Village}

In 2009-10, I spent twelve months in Aceh conducting fieldwork in two different locations. Blang Daruet is a Banda Aceh neighborhood, which was destroyed during the 2004 Indian Ocean tsunami, and rebuilt afterwards. ${ }^{74}$ Desa Jurong is a small village in Aceh Besar, located just off the main road from Banda Aceh to Medan. ${ }^{75}$ In both locations, vigilante violence occasionally occurred. I will give two examples, one for each location.

About half a year before I came to Daruet, a young couple there was accused of adultery (zina). The couple was not originally from Daruet-the woman came from the mountainous area of Gayo (in the central highlands), while the man was from West Aceh. Both of them lived in Daruet alone, on the same street but in separate houses. Their neighbors had become suspicious when seeing the woman visiting the man's house in the evening. Eventually, a group of villagers, mostly young men aged between their late teens and early thirties, mobilized in front of the house to catch the two "in the act." The couple was dragged out of the house, the woman covered only in sheets. On the street, the man was beaten, and the woman's hair was cut short. Afterwards, both of them were "given a bath" (dimandikan, or siram) using filthy water from the gutter. When this public cleansing was done, village leaders contacted the authorities. The couple was taken on the back of a motorcycle to the police station and held for a few days. In the meantime, their parents were summoned to Banda Aceh. Upon their arrival, consultations (musyawarah) were held to discuss the way in which the case should be "solved" (diselesaikan). Ultimately, matters were settled when the couple was married in the Blang Daruet mosque-an event witnessed by many of the local residents. Immediately thereafter, the newlyweds moved away from Daruet. The village head (geuchik, commonly addressed as Pak Geuchik) told me that he had "no idea" where the couple had gone.

\footnotetext{
73 "Mirza terjaring di jaring Facebook"; “Disaksikan Ribuan Jemaah Salat Jumat, Mirza Alfath Ucapkan Dua Kalimat Syahadat," November 23, 2012, http:/ / atjehpost.com/read/2012/11/23/28868/15/5/ Disaksikan-Ribuan-Jemaah-Salat-Jumat-Mirza-Alfath-Ucapkan-Dua-Kalimat-Syahadat, accessed December 29, 2012.

${ }^{74}$ A staggering 75 percent of about three thousand total inhabitants of Blang Daruet died as a result of the tsunami. The neighborhood was physically reconstructed with the help of two international NGOs. When I arrived in 2009, almost all of the survivors had been given a house in which to live.

${ }^{75}$ All names referring to people in these two places are pseudonyms.
} 
Hussein (age twenty-one) was one of the young men who took part in the "arrest." When I asked him why such rough treatment was necessary, he gave various reasons. Firstly, he argued, the couple was supposed to "learn what shame was" (supaya dia tahu malu). Moreover, their treatment was meant as a "warning" (peringatan), not only to this couple but also to others, that such conduct was not allowed in Daruet. Only in this way, Hussein went on, would it be possible to ensure the "good name" of Blang Daruet. "If we are soft on them, people in other villages will think that you can do whatever you like in Daruet, that it is just free here [bebas aja]. The village would attract even more sinfulness [tarik maksiat lagi]." He also claimed that "every village throughout Aceh [seluruh Aceh]" would react like this.

About the role of local community leaders, different versions circulated. According to the geuchik, he was not present at the "arrest." He was only alerted when the beatings and the "cleansing" had already taken place. According to Hussein, as well as others involved, however, both he and the village imam had been present, standing at the back. Regardless of the question of who was speaking the truth, the important point is that, according to the geuchik, the arrest was the "business of the pemuda," ${ }^{76}$ and he did not consider it his duty to interfere. As Hussein formulated it, "Pak Geuchik just makes sure we do not beat them to death." When I asked "how much" of a beating should suffice, Hussein answered: "we beat them until we felt satisfied" (dipukul sampai puas).

This does not mean that there was no debate in Daruet about whether this kind of violence constituted a proper response to what had happened. I often heard people explain that "actually" the beatings and the practice of washing the wrongdoers should not be allowed, but that it was difficult to "contain" the youth. Also, people generally thought that public anxiety about sexual transgressions (mainly khalwat and zina) had increased significantly after the tsunami.

The incident in Jurong concerns a khalwat (seclusion) case, which I witnessed-at least partly-myself. In early 2010, two teenagers were "caught" (ditangkap) while sitting underneath the house of the girl's grandmother, who was a Jurong resident. The boy and the girl came from different villages, and knew each other from school. The girl often visited her grandmother (who lived in the house together with her adult son and another granddaughter). The group of villagers who came to "arrest" the couple comprised five or six young men. Later, they were joined by a dozen others. The pair was taken to the village communal hall (meunasah). On the way, the boy received repeated blows on the arms and chest (not on the face). At the meunasah, the couple was drenched with (clean) water from the tank of the meunasah. After the cleansing, village leaders were alerted, including the geuchik, the imam, and one of the leaders of the adjacent Islamic boarding school, who was also the head of the Jurong village council (teuha peut). A meeting was called (musyawarah), during which the parents of the boy and girl were contacted, and directed to come to Jurong. After the parents arrived, some village leaders suggested that the couple be married in the dayah mosque, but this "solution" was rejected. Instead, the parents apologized to the kampung leaders, after which they were allowed to take their children home.

\footnotetext{
${ }^{76}$ Pemuda means "youth" or "young men," and often refers to young men in groups, or gangs. I will return to the meaning of this term in the next section.
} 
One of the key players in this incident was the "head" of the village pemuda, Syihab (age twenty-eight). When I asked him, a couple of days after the incident, how he viewed the arrest, he answered that, "in Jurong, village law applies [hukum kampung berlaku]. It is allowed to receive guests at night, but not to meet in dark spots or in the shrubs [semak-semak]. We have rules." Syihab had taken the initiative for the arrest, but he regarded all (male) pemuda to be responsible. He mentioned two reasons in particular. Firstly, illicit behavior such as khalwat had "damaging" effects on the moral integrity of the Jurong residents (merusakkan warga). It was the task of the pemuda, he explained, to protect the "good name" of the village. He regarded it as irresponsible to "just let pass" (dibiarin aja) such behavior, because the people of Jurong would feel ashamed for their village. The second reason was that "state law" (hukum negara, as opposed to adat) was, in his view, utterly unreliable. "If we revert to state law, perhaps [the problem] won't be dealt with ... We have seen that often enough." This was an argument I heard often, both in Blang Daruet and in Jurong.

The geuchik arrived late on the scene, after the beating and the cleansing had taken place. When asked about the role of the pemuda, the geuchik was ambiguous. In his view, the pemuda were allowed to arrest people-heavy-handedly if necessary-but not to carry out punishments. He did not approve of the beatings and the cleansing. This punishment was "too harsh" (terlalu keras) and "forbidden by Islam" (agama melarang). He occasionally told the pemuda to be calm, but at the same time he stated that this was difficult "if emotions are in play" (kalau sudah emosi). There were, in other words, limits to his authority. "I can only speak tough to them" (saya bisa ngomong kasar dengan mereka). But apparently, this did not always have much effect. A somewhat different view was advanced by Abi, the dayah leader and head of the teuha peut. Just like the village head, he arrived on the scene after the public shaming had taken place, and, unlike the geuchik, he agreed with the punishment. "As kampung leaders, we often remind the people about the rules, so this is the logical consequence." The main condition, he argued, was that no lasting physical damage was inflicted, for that might cause retaliations or even damages to be paid by the village (an important part of adat law). He was also less ambiguous about the pemuda. They functioned as a kind of "village police," he argued. At the same time, he acknowledged that there was a risk, because "children [are] difficult to control" (anak muda, susah dikontrol).

The young woman's Uncle Nasir, who lived in the house where the "arrest" had taken place, was furious with the pemuda. At the time the uncle was alerted, the cleansing at the meunasah had already taken place. However, he decided not to make a scene. He explained to me that this would only have made matters worse, given the excitement of the pemuda. At this point, he stated, it was the task of the village leadership to "cool them down" (dikasih dingin). Importantly, however, he did not contest the general opinion that cases of khalwat should be settled within the village, and on the basis of adat law. The pemuda acted wrongly for three reasons. Firstly, at the time of arrest, it had been nine o'clock in the evening, one hour before the time limit stipulated by a village regulation on adat law (meaning, it was not forbidden for the young people to be together at that time; I will return to this matter in the next section). Secondly, he said, while pointing out two light bulbs on both sides of the house, the only "dark spot" was behind the house, and this is not where the couple had been sitting at the time of their arrest. Thirdly, the family had not been given a proper warning in advance, which, in his view, was certainly a necessary condition. The 
arrest, in other words, had been illegitimate. "When I ran into Syihab the other day," Nasir told me, "he did not dare to look me in the eye. He feels ashamed, because he knows he got it wrong." In the meantime, shame had been put on his family, for reasons he deemed unlawful.

\section{The Pango Raya Bridge}

This case centers on the location of a new bridge, connecting the Ulee Kareng district in Banda Aceh to the main road to Medan. The bridge is located next to the village of Pango Raya, Aceh Besar. During the first half of 2012, this became a popular spot for Banda Aceh youth to "hang out" (nongkrong). ${ }^{77}$ This situation was disturbed three months later, when the location became notorious as a place where violent responses against "sinful behavior," carried out by local youth from Pango village, had been enacted. Many of these cases involved young courting couples (some of whom might have viewed the bridge as a romantic location, while others might have been interested primarily in finding a "dark spot," for the bridge was still partly a construction site). The bridge became a topic for the media in October, when the vicemayor of Banda Aceh, Illiza Sa'aduddin Djamal (of the national Islamic party PPP), decided to visit Pango at night, together with the syariah police, to help the villagers "restore" the moral order.

The policing actions of the Pango youth have been occasionally violent, with some accused wrongdoers getting severely beaten. As far as I can tell, people have not been beaten to death, although several have ended up in the hospital. In one case, the situation almost escalated when a (male) police officer threatened the youth with a gun. No shots were fired, however, and the villagers ultimately persuaded the man and his female companion to leave the location. ${ }^{78}$ In December 2012, I talked to three of the young men involved in the "policing" of the Pango Raya Bridge. They were between eighteen and twenty-three years old, and when they spoke about their motivations for engaging in regular nightly patrols, they did so in terms of "preventing sinful behavior," and "protecting the village" against the dangers coming from outside.

Compared to the cases described above, the role of the geuchik, Kamaruzzaman, is rather remarkable. According to these youth, it was the village head who first "ordered" them to patrol at the bridge and to "throw out" (mengusir) unwanted elements. To facilitate these actions, the pemuda were provided with coffee and cigarettes (not money). The actions were approved by the local police chief. After a few months, the geuchik arranged for a number of big signs to be put up at the bridge,

\footnotetext{
${ }^{77}$ As the Atjeh Post website reported in May 2012, "The long and wide bridge at Pango Raya functions not only as a place for traffic and transport. It has also become a cool place for killing time, especially in the late afternoon, while waiting for the sun to set. Or at night, while enjoying the flickering stars in the vast and infinite sky. Since a few months now this bridge is becoming an alternative place for hanging out for the people of Banda Aceh. Particularly for young people who want to spend their time at dusk together with their friends of the same age." "Jembatan Pango, Tempat Konkow Baru Kawula Muda Banda Aceh," May 25, 2012, http:/ / pemerintah.atjehpost.com/read/2012/05/25/10031/60/60/ Jembatan-PangoTempat-Konkow-Baru-Kawula-Muda-Banda-Aceh, accessed December 29, 2012.

${ }^{78}$ Most of the information in this section is derived from an interview I had with some of the Pango youth, as explained below.
} 
reading, "Beware! It is forbidden to stay on the bridge at night. At your own risk. [Signed] Team Community Pango. ${ }^{\prime 79}$ My interlocutors emphasized the significance of these signs, both in relation to their own role, and that of the village leadership. While it was the geuchik who "took responsibility" by ordering the pemuda to start patrolling, the signs were understood, essentially, as evidence that the geuchik had relinquished that same responsibility, giving the pemuda "free rein" on the bridge. "The geuchik has pulled his hands away from it" (geuchik sudah lepas tangan).

While the geuchik thus played an important role initially, the pemuda were more than willing to take up the task. As these young men explained it to me, it was important to counter and discourage "transgressions of village norms" (pelanggaran norma-norma kampung). By this they meant especially sexual norms: the prohibition of (sexual) "immorality" (mesum), illicit "relations" (perhubungan), proximity (khalwat), and adultery (zina); but also other disturbances of public order. Thus, in their explanations they shifted automatically from chasing away courting couples to engaging in a large brawl with a motorcycle gang. ${ }^{80}$ Allowing such behavior would give the outside world the impression that Pango was a "free haven" (tempat bebas), or a "village full of adultery" (kampung zina). As was true for their counterparts in Daruet and Jurong, the actions by the pemuda were directed at protecting the "good name" (nama baik) of the village. Through the construction of the bridge, the youth argued, Kampung Pango Raya had been given a bad name (sudah jelek nama kampung). Violence was sometimes unavoidable, they explained, for they were occasionally met with resistance. Equally important, however, was the fact that these actions were supposed to have a "deterrent effect" (efek jera) on all "sinners" who otherwise might come there.

As mentioned already, a significant factor in the Pango case was the interest and presence of vice-mayor of Banda Aceh, Illiza Sa'aduddin Djamal. On October 26, 2012, Illiza visited Pango, in the company of the head of the Ulee Kareng Subdistrict and the head of the provincial Adat council (MAA), to perform a number of adat rituals together with the village Women's Council (Pembinaan Kesejahtaraan Keluarga, PKK). She stated that, by doing so, she expressed her "support for local customs [adatistiadat], especially those which are infused by Islam [yang Islami] and those which do not contradict syariah." ${ }^{81}$ A few weeks later, on October 13, Illiza visited Pango again, this time at night and in the company of the syariah police and a number of "community organizations" (organisasi masyarakat), to carry out a raid at the bridge together with Pango villagers. ${ }^{82}$ At this event, which was widely covered in the press, Geuchik Kamaruzzaman stated that "the Pango Bridge has become a location for hanging out by young couples who are not muhrim [closely related by kin]. This location has even been used as a place for using drugs and as a site for illegal road racing." Illiza, on her part, announced the "formation" of the Tim Amar Ma'ruh Nahi Mungkar Gampong Pango (Team Encouraging Good and Forbidding Evil), consisting

\footnotetext{
79 "Awas ... ! Dilarang duduk di atas jembatan para malam hari. Risiko tanggung sendiri. Tim Masyarakat Pango Raya."

${ }^{80}$ Interestingly, they referred to these gangs as "punk groups." As Reza Idria explained it to me, in the public opinion in Aceh, a "punk" lifestyle represents all kinds of "sinful," or socially undesirable, behavior Personal communication, December 2012; see also Reza Idria, "Muslim punks and state Shari'a," in Feener et. al, Islam and the Limits of the State.

81 "Illiza Serahkan Sange untuk Warga Pango," Serambi Indonesia, September 27, 2012.

82 “Ratusan Warga 'Razia' Muda-Mudi di Jembatan Pango," Serambi Indonesia, October 14, 2012.
} 
of Pango villagers. According to the vice-mayor, the problem of syariah offences had "escalated" in Banda Aceh. ${ }^{83}$

Illiza's focus on syariah is hardly surprising. During the past years, the strengthening of Islamic law has been a spearhead issue in her political campaigns, especially in the run-up to elections. However, for the three young people whom I interviewed, Islamic law hardly played a role. The only time they referred to the particularities of syariah was in the context of Illiza's visit, and when noting that it was impossible for the WH to patrol the bridge twenty-four hours a day.

\section{Vigilante Violence and the Struggle for Moral Authority}

It is now possible to analyze at a deeper level the positions, attitudes, and agencies of different actors involved in carrying out, staging, facilitating, legitimizing, or encouraging vigilante violence. As I have argued, contrary to the standard narrative of Acehnese history and society, it is important to ask how the state has become embedded in Acehnese (village) society, how this process is tied to conflicting interests and particular patterns of social interaction, and how these changing configurations affect, in turn, the contestations about moral authority currently taking place. As foreshadowed in previous sections, a central aspect is formed by the ways in which different actors, including village leaders, religious leaders, local youth, and agents of the state approach and make use of the concepts of law (hukum) and justice (keadilan), and what happens when, evoking once more the work of Joshua Barker, the state engages with local conceptualizations of "territoriality." ${ }^{84}$

Generally, I found, village leaders do not agree that it is acceptable to use violence against accused violators of public morality norms. This was my experience in Blang Daruet and Jurong, but also in other places I visited. Although my interlocutors used different words to express their thoughts, it usually came down to the combined argument that beatings and public "cleansings" are neither Islamic nor proper adat punishments. Ideally, then, the village leadership should be warned before any punitive action takes place, while village consultations (musyawarah) should preclude any punishment. "Containing" excited youth, and preventing "anarchy" (anarki) was commonly seen as the responsibility of village leaders. However, I was often told by village leaders themselves that it was difficult to "contain" the pemuda, and that officials often only became involved after the violence had already taken place. One possible explanation for this situation is that, in recent years, village leaders-and especially the geuchik - have been given more and more responsibilities. As a result, they are increasingly unable to keep all village affairs under control. While village heads are considered to be adat leaders, who are chosen by the villagers, they are also increasingly seen as agents of the state who need to broker government support and

\footnotetext{
${ }^{83}$ For this reason, Illiza stated, the government remained committed to the enforcement of syariah. Still, she added, the involvement and the support of the [local] community is an issue of the greatest importance. Without the support of [local] residents, these efforts would be in vain. Illiza said, "The Tim Amar Ma'ruh Nahi Mungkar, which has already been formed in two villages, namely Kuta Alam and Pango Raya, has the authority to keep watch over every breach of syariah that occurs in each respective area, by means of persuasion, not by means of violence." Quoted from "Ratusan Warga 'Razia' Muda-Mudi di Jembatan Pango," Serambi Indonesia, October 14, 2012.

${ }^{84}$ Barker, "Surveillance and Territoriality in Bandung."
} 
successfully apply for state programs directed at village "development." This double role often leads to an entanglement of interests, and-sometimes-to a serious compromising of a geuchik's moral authority.

In fact, public order-and especially the (often tediously elongated) processes of consultation (musyawarah) and appeasement (perdamaian)-is one sphere in which village leaders can try to lighten their traditional "burden." This seems to be especially true in the sensitive cases related to accusations of deviancy. In the cases of Tuengku Aiyub and Mirza Alfath, village leaders ostentatiously refrained from claiming public responsibility. ${ }^{85}$ In the case of Pango Raya, the geuchik took "forceful action," only to negate all personal responsibility a few months later when he put up a few signs. This process of refusing responsibility has a flipside, however. There is, throughout Aceh, a genuine concern about the "unclarity" of adat regulations. It is a new trend, then, that village leaders try to formulate and "officialize" adat regulations. In Jurong, such a document was first drafted in 2009 , although it was still rudimentary in its phrasing. ${ }^{86}$ In Daruet, the village leadership was working on a qanun gampong (village bylaw), which was supposed to contain village rules as well as regulations regarding the enforcement of adat.

Moral authority is not limited to village leadership. In particular, the analysis of vigilante violence should be extended to the role of religious leaders. As James Siegel showed in his classic ethnography of village life in Pidie (North Aceh), in the 1950s Acehnese society was characterized by a rather sharp separation between the social spheres of the village (gampong) and the institutions of religious scholarship (dayah, or pesantren).$^{87}$ Today, this is much less the case. Although the dayah still represent a distinct social setting, with its own norms and codes of conduct, in practice the boundaries between village, dayah, and state have become blurred. In the village of Jurong, ulama from the nearby dayah combined their role as religious leaders with positions in the village administration. At the same time, both ulama dayah and members of (local branches of) the MPU actively interfere in local communities, both in urban and rural settings, and not seldom after being actively solicited by community leaders. Complicating matters even further, ulama dayah are regarded by ordinary Acehnese not just as religious leaders, but also as adat leaders (tokoh adat).

The ulama in Jurong told me that they did not approve of the use of violence by the pemuda, but that they could do little to prevent it. In fact, indecisiveness is a more general pattern in the stance of ulama toward (potentially) violent conflicts and incidents. In some cases, this stance seems to be connected to political calculation,

\footnotetext{
${ }^{85}$ In the case of Mirza Alfath, village leaders emphasized that he had come to Desa Keude Aceh only recently, and that they knew very little about him. "Mirza terjaring di jaring Facebook."

${ }^{86}$ In January 2009, the village leadership of Jurong issued an "announcement" (pengumuman), which was signed by the geuchik, the different members of the teuha peut, and the kepala pemuda, and copies were sent to the Camat (Subdistrict Head) and the Kapolsek (local chief of police). The document consists of five brief statements. The first two concern "customary sanctions" (sangsi adat) for thieves. The final three are of a more general nature, stating that "guests may not enter the village after ten o'clock at night," "guests who want to spend the night have to report to the assistant village head [ketua lorong]," and "those who are in the company of a girl who is not close family [muhrim] at night have to be arrested" (ditangkap). At a later meeting, these provisions were further elaborated upon, but those refinements were not included in any official document. During this meeting it was decided that violators of public morality (such as those drinking alcohol, or engaging in khalwat) should receive three warnings before being "arrested."

${ }^{87}$ Siegel, The Rope of God.
} 
according to which it seems more strategic to remain "silent" than to stand up for (and make the impression of "defending") alleged wrongdoers. In other cases, it is due to the simple fact that there is no consensus among the ulama regarding what does, and what does not, constitute proper adat "enforcement." The chairman of the MPU, Ghazali M. Syah, told me in an interview that he did not have a problem with the practice of public "cleansing," which he viewed as a "legitimate" adat punishment. He did not even regard the practice to be a form of violence, because it does not inflict "physical" damage. ${ }^{88}$ In contrast, Vice-Chairman Teungku Faisal Ali (who, incidentally, has been one of the most prominent and vocal pro-syariah activists in Aceh in recent years) stated that this punishment is permitted neither by adat nor by Islam, and should be discouraged as much as possible. ${ }^{89}$

Of course, debate and differences of opinion are a key aspect of traditional Islamic scholarship. The problem, then, is that the MPU is a state institution, and that the confusion about what should and should not be allowed has a particular impact on the way in which the body functions. The case of Teungku Aiyub is a good example. As said, when violence broke out in November 2012, the controversy about Teungku Aiyub's teachings, and the alleged activities in which his group engaged, had been dragging along for at least two years. In fact, this was not the first time that a large mob gathered in front of his house. This had happened before, in March 2011. ${ }^{90}$ At that time, Teungku Aiyub was "brought into safety" by the police. In response, the districtlevel Ulama Council carried out an investigation, though without reaching a clear conclusion. ${ }^{91}$ One of the reasons why the conflict kept festering, then, was that the MPU never decided whether the group should be considered a "deviant sect" (aliran sesat). ${ }^{92}$ Ironically, it was only after the killing of Teungku Aiyub that the MPU, by word of its Vice-Chairman Teungku H. Jamaluddin, declared that his group did not represent a deviant sect. ${ }^{93}$ In the case of Mirza Alfath, the MPU reacted less indecisively. However, in public statements the blame for the incident was placed entirely on Mirza Alfath, while the aggressive demeanor of the crowd was hardly called into question. ${ }^{94}$ Also, no attempts were made by religious leaders involved in

\footnotetext{
${ }^{88}$ Interview with Ghazali M. Syah, December 11, 2012.

${ }^{89}$ Interview with Teungku Faisal Ali, December 11, 2012.

90 "Satu lagi: soal dugaan ajaran sesat!" Modus Aceh, March 31, 2011. In this incident, disagreement did not result in a clash. However, the mob did burn down Teungku Aiyub's balai (shelter used for teaching), and set fire to a vehicle.

${ }^{91}$ Ibid.; "Wawancara Sekretaris MPU Bireuen: Jangan terlalu mudah menggolongkan seseorang sesat," November 18, 2012, http: / / atjehpost.com/ read/2012/11/18/28205/15/5/Wawancara-Sekretaris-MPUBireuen-Jangan-Terlalu-Mudah-Menggolongkan-Seseorang-Sesat-, accessed December 29, 2012. The only conclusion from this earlier investigation was that Teungku Aiyub should be forbidden to teach adults because he did not possess enough knowledge-not because his teachings were subversive.

${ }_{92}$ In the aftermath of the March 2011 incident, MPU Bireuen chairman Teungku Hanafiah Hamza blamed Teungku Aiyub's unwillingness to cooperate in the investigation for the fact that it was "difficult to come to a conclusion" about his teachings. "Malam berdarah di Jambo Dalam."

93 "Bentrok Bireuen, Ulama: Tak Terbukti Ajaran Sesat," November 17, 2012, http: / www.tempo.co/ $\mathrm{read} /$ news / 2012/11/17/058442329/Bentrok-Bireuen-Ulama-Tak-Terbukti-Ajaran-Sesat, accessed July 29 , 2014.

${ }^{94}$ After meeting with Mirza and interrogating him about his Facebook postings, the MPU concluded that, "if he wants to ask forgiveness in front of the community [masyarakat] and pronounces the confession of faith [mengucap dua kalimah syahadat] and promises not to do this again, Mirza may be allowed to return to his house." "Mirza terjaring di jaring Facebook."
} 
this case to defuse the disturbing rumors that immediately surrounded the person of Mirza as soon as his Facebook postings became an issue in the media. ${ }^{95}$

In order to assess the effects of these changing leadership roles, it is necessary to look closely at the perpetrators, and, in particular, the salient role of the semiinstitutionalized, young male adults commonly designated as pemuda. In Indonesia, the term pemuda has a specific genealogy, which goes back to the struggle for independence in the 1940s. ${ }^{96}$ Here, what concerns me most is the tradition of (organized) pemuda to depict themselves as representatives of particular territories (mostly the neighborhood, or the village), their pragmatic engagement with different moral frameworks (including syariah and adat), and the way in which their references to a "deeper solidarity" challenge established forms of authority. ${ }^{97}$ Typically, the pemuda emphasize their responsibility of guarding the village against "disruptions" and bad influences from "outside." The latter may include thieves, but also public morality breaches. As Syihab, the "head of the pemuda" in Jurong, phrased it, the pemuda are those "in front" (di depan), taking care of the boundary between the domain of village integrity and the "outside world." The motivation I heard time and time and again, in Daruet, Jurong, and Pango, was the need to "protect the good name of the kampung."

One factor to take seriously here is a culturally embedded view of masculinity, which, in Aceh, builds both on traditions of gender segregation and on the history of (armed) conflict. It is often stated in Aceh that young men are "hot-blooded" (darah panas) and that they are easily "agitated" (cepat emosi). Acehnese masculinity and the responsibility of protecting the kampung against outside influences are interrelated. The young men in Pango Raya gave various explanations for the use of violence in their attempts to "clear" Pango Bridge from unwanted elements. People might not be "deterred" sufficiently, or there might be resistance. But they also freely admitted that taking a hard stance felt good. Violence and intimidation were part and parcel of a process of cultivating group loyalty and cohesiveness (kekompakkan). To "defend" the good name of the village gave them a feeling of "personal pride" (kebanggaan sendiri). The visit by the vice-mayor added to this feeling. They were proud to be regarded as an "anti-sinning movement" (gerakan anti-maksiat) and joked that the vice-mayor regarded them as the "village WH."

\footnotetext{
${ }^{95}$ Take, for example, a rumor reproduced in a report in Modus Aceh. According to the reporter, it was told in the neighborhood that, shortly after the police had come to form a "defense line" in front of Mirza's house, a mysterious girl had come forward from the crowd. This girl then pointed at a spot on the facade, after which she called out: "That is the image of the sun, like the symbol found in the beliefs of the illuminati." Subsequently, the reporter ominously comments, "Indeed, in ancient Egyptian mythology the sun is a symbol of Dewa Ra. In Judaism, Dewa Ra is claimed to be one of their Gods [sic]. In synagogues, it is common to display signs of the sun. So is this deliberate or a mere coincidence? Who knows, perhaps only the owner is able to tell." "Mirza terjaring di jaring Facebook."

${ }^{96}$ In Java, youth groups manifested themselves as revolutionaries par excellence. Benedict Anderson, in his seminal work on Java during the Revolution, explained this by pointing at the specific place of youth in traditional Javanese society, with the temporary withdrawal from the village through enrolment in the pesantren being the primary rite de passage. Benedict R. O'G. Anderson, Java in a Time of Revolution (Ithaca, NY: Cornell University Press, 1972), pp. 1-15. In Aceh, organized youth groups (including the Pemuda PUSA) also played a central role in the struggle. See Anthony Reid, The Blood of the People: Revolution and the End of Traditional Rule in Northern Sumatra (Kuala Lampur: OUP South East Asia, 1980).

${ }^{97}$ Anderson, Java in a Time of Revolution, p. 186.
} 
Of course, not all vigilante violence is carried out by the pemuda. Thus, the process of constructing localities must be viewed within a broader social and discursive context. In both my field sites, a clear distinction was made between "original inhabitants" (people who were born in the kampung) and "newcomers" (people who had come to live there recently, or people who came to visit or stay temporarily). With regard to moral transgressions (including khalwat and zina, but also, for example, alcohol use or more mundane criminal offences such as stealing), the stance of local villagers tended to be much harsher toward newcomers than toward original inhabitants. It was often explained to me that, if "original villagers" were caught in immoral behavior, the village leadership would try to solve the case in a relatively soft and inconspicuous way. However, when outsiders misbehaved, this was framed much more as a disturbance to the moral integrity of the village, soliciting a tough response. The explanation was often the same: if newcomers were not dealt with adequately, this may create rumors about their village being "free" (bebas) and unconcerned about sinful behavior, thus staining the good name of the village.

The place of state syariah in this discourse is ambiguous. Saiful, a thirty-year-old Daruet resident, once asked me whether I had witnessed a public caning. I answered I had not, upon which he said: "You should go. Many people come and watch." I asked him whether a caning had ever taken place in Daruet. "No," he said. "But this does not mean that there have not been violations of syariah [pelanggaran Syariat], there have been many!" Most cases, he explained, were handled "internally" to protect the name of Daruet. "Just so that the newspapers don't start writing that the people of Daruet this, the people of Daruet that [warga Daruet begini, warga Daruet begitu]. When people come to Daruet from outside [dari luar], and do bad things here [hal jahat], only then [do] we call in the WH." During my conversations with Syihab, the term "syariah" was seldom mentioned. The only time that he referred to the system of state syariah was when he explained that the WH was an inadequate institution, which, moreover, never came to Jurong. This does not mean that he perceived the institutions of "state law" (hukum negara), including the ("ordinary") police, to be more adequate. The crucial issue was not the distinction between "religious" and "secular" law, but the fact that he did not regard the reputation of his village as a responsibility of the state.

In fact, this view is shared by many representatives of the state, particularly the police. Often, the pemuda are not held accountable for their actions, and, as we have seen, in some cases vigilantes are even openly supported by the police. When the police do take action, as in the case of Teungku Aiyub, in Plimbang, their response often seems inadequate. To some extent, this may be ascribed to slackness. An often underestimated factor, however, is fear. One of my interlocutors in Blang Daruet explained that people "know how to use a weapon." Cases such as the outbreak in Plimbang show that local police officers are under-equipped, underfinanced, and under-supported by the government, which means that, even if the police want to, it is difficult to ensure other people's safety without compromising their own. ${ }^{98}$ With

\footnotetext{
${ }^{98}$ A particularly disturbing fact in the Teungku Aiyub case is that, although the police were on the scene after the initial clash, when the mob came back for the second time-this time with many more peoplethe police were unable to keep the situation under control. Ultimately, Teungku Aiyub was shot by the police in both his legs. The police chief later declared that they were forced to do so when Teungku Aiyub launched an attack with a sword. After this, they could not prevent the killing of Teungku Aiyub, and the mutilation of his body. "Polisi: Penembakan Teungku Aiyub Sesuai Prosedur," November 17, 2012,
} 
regard to the numerous instances of small-scale violence, a more important factor seems to be the conviction on the side of state authorities that some problems are better left to local communities to resolve. In fact, it seems that local conflicts (including public morality breaches) are increasingly viewed as "village" matters, which should not concern the police. ${ }^{99}$ This sometimes leads to confusion, particularly when cases are actively "handed back" to village communities by the police after reports have already been filed.

This situation is not generally or categorically rejected by local communities. As I have explained, people in Aceh often do not have much trust in (state) law "running its course" (hukum berjalan). At the same time, however, it is important for most people that the routes to conflict resolution by means of state law (hukum negara) are not entirely shut off. Most people think that the use of adat law should be open to some kind of appeal. An interesting development, in this respect, is formed by the attempts to integrate, more systematically than before, adat law with police tasks, in a government program known as polisi masyarakat (polmas, "community police"). ${ }^{100}$ In the polmas program, village communities are asked by the police to designate one member of the village council (teuha peut) to act as a police "counterpart" in addressing adat breaches, making sure that public morality issues (such as khalwat and zina) are solved without the use of violence. As one spokesperson of an Acehnese community-based NGO expressed it to me, the polmas concept constitutes a potentially revolutionary attempt at increasing trust between local communities and the state security system. ${ }^{101}$ In this design, cases are not just "given back" to the community to solve, but the local village community becomes a more integral part of the law-enforcement structure. Time will have to tell whether this model has a future.

\section{A Society in Flux}

In this essay I have looked at the views and actions of vigilantes, community leaders, and state agents in order to investigate the dynamics of public morality and vigilante violence in Aceh. Post-conflict, post-disaster Aceh is a society in flux, and in recent years concerns about "correct" behavior have been propelled to the forefront of political debate. A central element of this process is the content and enforcement of Islamic law (syariah), implemented in the region since the early 2000s. Some local

http:/ / www.acehkita.com/ berita/ polisi-penembakan-teungku-aiyun-sesuai-prosedur / , accessed July 29, 2014.

${ }^{99}$ This is confirmed by a Human Rights Watch report, which quotes the chief of police in the Baiturrahman subdistrict, Banda Aceh, explaining that the police rarely apprehend the perpetrators of violence in khalwat cases: "We never arrest people for that kind of violence, because it's hard to prove who was the actor, or the couple didn't see who it was. And if it was committed by many people, we can't arrest them all." Human Rights Watch, "Policing Morality," p. 49.

${ }^{100}$ An interesting initiative, in this respect, is the cooperation among the provincial police force (Kepolisian Daerah Nanggroe Aceh Darussalam), the International Organization for Migration (IOM), and IAIN ArRaniry under the title Forum Kemitraan Polisi dan Masyarakat (Forum for Police-Society Partnership). See M. Jamil Yusuf, Syukri Syamaun, and Fairus M. Nur Ibrahim, eds., Polmas dan HAM: Dengan pendekatan Dakwah dan adat budaya Aceh (Banda Aceh: Polda Nanggroe Aceh Darussalam dan Fakultas Dakwah IAIN Ar-Raniry, 2009). For a more general perspective, see Kepolisian Negara Republik Indonesia (Polri), Polmas: Paradigma baru Polri (2010).

${ }^{101}$ Interview, Sanusi Syarif, Yayasan Rumpun Bambu, December 14, 2012. 
activist and paramilitary groups have carried out raids, violent actions, and punishments to "help" the government in its implementation of syariah. Religious and political leaders occasionally support this violence, stating that it constitutes a proper way of dealing with moral decline, failing authorities, or both. Not seldom, these leaders take a decidedly "pro-syariah" stance. Vigilante violence "in the name of syariah," while situated at the margins of (social and political) activism, is a reality in contemporary Aceh. The social and political mechanisms that underlie this kind of violence cannot, however, explain the outbursts through which ordinary villagers have tried to purge their own living environments of moral transgressions. In many such cases, syariah is not the central issue. Instead, perpetrators, often local young males, point to the need of protecting the "good name" of their village through upholding local customs or village law.

Claims to adat form a neglected aspect of contemporary contestations about public space and "correct" behavior in Aceh. Just like syariah, the concept of adat is subject to continuous reconfiguration, both by the state and by ordinary villagers. Most Acehnese value a legal system that consists of a combination of secular law, Islamic law, and customary law. Balancing these normative frameworks is difficult, however, since in practice the distinction between "traditional" (village) institutions (crucial for adat law to come into effect) and the state is not very evident. The sharp line that is often drawn between "Aceh" and "Indonesia" tends to hide from view the embeddedness of the state in village society. Rather than view the outbreak of vigilante violence as a matter to be engaged either by the state or by "traditional" leaders, then, in this article I have sought to demonstrate how these spheres of authority interact.

The competition for power and resources in post-New Order Indonesia has come with drastic social and political changes. In Aceh, where people are trying to come to terms with a history of great suffering and human loss, it has produced a pervasive, ongoing, and as yet largely undecided struggle for moral authority. This article departs from much of the literature about this subject by analyzing how this process works at the level of the village. One of the major strategies that many ordinary villagers pursue in order to strengthen their position in this struggle for authority is to guard, protect, or attain a sense of order at the level of the hyper-local: a village, a ward, a road, or a bridge. Vigilantes, by virtue of their appeal to territory and the reputation of local communities, are an integral part of this process. While local leaders often do not approve of vigilantism, they also experience difficulties in containing it. This, I have argued, results at least partly from the internal contradictions vested in their position. Local authorities, including village heads and religious experts, are commonly regarded as state agents and community leaders at the same time. Thus, they are expected, on the one hand, to manage the village as a point of access to the economic and legal resources of the state, and, on the other hand, to protect the moral space of the village against internal and external threats. The ability to reconcile these different roles depends partly on the social status and personal character of individual leaders. At the same time, particular circumstances can be identified that compromise these leaders' authority. In many cases, such complications are related to contestations about village territory.

In places that were badly hit by the tsunami, like Blang Daruet, social and physical disruptions caused by the disaster affected community members' perceptions of the 
village leaders' efficacy, adding to the moral anxiety felt in the context of rebuilding communities. In villages that were not affected by the tsunami, however, similar problems and doubts also occur. In Jurong, the integrity of the village community had eroded as a result of a disruptive conflict over state resources. When local youth decided to protect the "good name" of their village, and acted violently against "improper" behavior taking place within the boundaries of their community, village leaders were too much at odds, and too much lacking in legitimacy, to call the pemuda to order. Another set of circumstances relates to the changing spatial connections and infrastructural reconfigurations resulting from the post-conflict focus on "development." The building of a new bridge at Pango Raya caused a sudden realignment of Pango village in a wider moral geography, leading villagersincluding the village head-to take violent action, and drawing the attention of a politician, thus causing further escalation through her attempts to strengthen her Islamic credentials. The tragic cases of Teungku Aiyub and Mirza Alfath, finally, show that, in some instances, conflicts that started out as relatively isolated affairs may transcend the moral spaces in which they first emerged. Thus, they may escalateoften under the influence of media reporting-out of proportion to the original (perceived) transgression. When many actors with different agendas decide to interfere, the risk of violence becomes more likely. Together, the cases discussed in this article show that the concept of, and control over, village territories constitutes a central aspect of the struggle for moral authority and vigilante violence in contemporary Aceh. 